Applied Catalysis B: Environmental 126 (2012) 275-289.

DOI: 10.1016/j.apcatb.2012.07.006

\title{
High-surface-area zinc aluminate supported silver catalysts for low-temperature SCR of NO with ethanol
}

\author{
Aurélien Flura, Fabien Can*, Xavier Courtois, Sébastien Royer and Daniel Duprez \\ Université de Poitiers - Institut de Chimie des Milieux et des Matériaux de Poitiers - IC2MP \\ UMR 7285 CNRS, 4 Rue Michel Brunet - Bât. B27, 86022 Poitiers Cedex, France \\ * Corresponding author. Tel.: +33-(0)549453997; fax: +33-(0)549453741 \\ E-mail address: fabien.can@univ-poitiers.fr
}

\begin{abstract}
The $\mathrm{NO}_{\mathrm{x}}$ selective catalytic reduction of ethanol (EtOH-SCR) was studied using a complex gas mixture representative of a diesel exhaust, over zinc alumina mixed oxide supported silver catalysts ( 2 wt.\% $\mathrm{Ag} / \mathrm{Zn}_{\mathrm{x}}-\mathrm{Al}_{2} \mathrm{O}_{3}$, with $\mathrm{x}=10-20-33$ at.\%). The supports were obtained using a template assisted sol-gel route in order to achieve high surface areas. For the higher Zn loading (33\%), the calcination temperature has been raised from $600^{\circ} \mathrm{C}$ to $800^{\circ} \mathrm{C}$ then $1000^{\circ} \mathrm{C}$ in order to evaluate thermal stability of these materials. Addition of zinc in alumina network leads to the formation of the spinel-type zinc aluminate structure. Chemical and physical characterizations of the catalysts have been confronted with the EtOH-SCR results, in order to understand the respective influence of the metal and support in nitrogen formation. This study shows that addition of zinc and modification of the support calcination temperature both play upon the Lewis acidic sites (LAS) concentration and density, determined by pyridine adsorption monitored by FTIR spectroscopy. This parameter is shown to be related with ammonia emission at $\mathrm{T} \geq 350^{\circ} \mathrm{C}$. Besides, formation of nitrogen at $\mathrm{T} \leq 350^{\circ} \mathrm{C}$ is shown to be dependent on (i) the rate of acetaldehyde formation and (ii) the reactivity of acetaldehyde in SCR of NO reaction. Modification of the alumina support directly impacts these parameters. Finally, it is demonstrated that $\mathrm{Zn}$ is a hopeful candidate to increase the EtOH-SCR activity at low temperature $\left(\mathrm{T} \leq 300^{\circ} \mathrm{C}\right)$.
\end{abstract}

Keywords: $\mathrm{Ag} / \mathrm{Zn}-\mathrm{Al}_{2} \mathrm{O}_{3}$, ethanol, $\mathrm{SCR}, \mathrm{NOx}, \mathrm{NH}_{3}$ 


\section{Introduction}

The current environmental legislations lead to increase the interest in Diesel engines technology from automobile manufacturers. Compared to gasoline engines, Diesel engines work in leanburn conditions, which lead to decrease the carbon dioxide emissions. However, $\mathrm{NO}_{\mathrm{x}}(\mathrm{NO}+$ $\mathrm{NO}_{2}$ ) contained in Diesel exhaust gas, i.e in oxidizing atmosphere, are hardly reduced into $\mathrm{N}_{2}$ using a conventional Three-Way Catalyst (TWC). Among the processes effective to reduce $\mathrm{NO}_{\mathrm{x}}$ in lean condition, two technologies are usually proposed in the literature: (i) the $\mathrm{NO}_{\mathrm{x}}$ Storage-Reduction (NSR) concept [1], working in transient conditions; and (ii) the Selective Catalytic Reduction (SCR). The SCR is described as a promising way to reduce $\mathrm{NO}_{\mathrm{x}}$, with the possible use of a large choice of reducers including unburned hydrocarbons, urea, ammonia, hydrogen or alcohol for instance. Actually, under the impulse of environmental legislation, the urea-SCR process is considered as a possible technological issue to reduce $\mathrm{NO}_{\mathrm{x}}$ from light vehicles, as reported in numerous publications [1-10]. This technology, usually applied for the $\mathrm{NO}_{\mathrm{x}}$ reduction from stationary sources, meet however some drawbacks to be transposed in $\mathrm{NO}_{\mathrm{x}}$ reduction of Diesel engines. First, even if the decomposition of the liquid urea solution (used as ammonia precursor) has been studied in the literature, urea hydrolysis is rather complex and not well understood yet. For instance, it was reported that in similar conditions, catalytic performances obtained with urea solution are largely lower than those obtained using ammonia [11]. Secondly, the thermal stability of zeolite exchanged transition metal $(\mathrm{Cu}, \mathrm{Fe})$, proposed for this application [12-14] in association with a Diesel particulates filter, does not seem to be fully mastered yet.

Hydrocarbon-SCR has been largely studied as well [15-23]. Recently, alumina supported silver catalysts $\left(\mathrm{Ag} / \mathrm{Al}_{2} \mathrm{O}_{3}\right)$ has taken particular interest [24-26], especially due to their reactivity toward oxygenated compounds. For instance, ethanol has been reported as an attractive reducer for the SCR reaction. Miyadera [27] showed that $\mathrm{Ag} / \mathrm{Al}_{2} \mathrm{O}_{3}$ catalyst is able to reduce $\mathrm{NO}_{\mathrm{x}}$ with ethanol in lean-burn conditions, from temperature as low as $250^{\circ} \mathrm{C}$. Compared to urea-SCR, the use of ethanol as a reducer agent can be justified by the existence of an ethanol-based fuel (such as E85) distribution network in numerous countries. Thereby, EtOH-SCR with mobile engine could easily be performed using a specific tank even if it would require an extra injector in the exhaust pipe, placed before the catalyst (same problem as urea addition, but ethanol is by far less corrosive). In addition, ethanol is a particularly attractive reducer candidate for $\mathrm{NO}_{\mathrm{x}}$ removal because it is environmentally relatively benign. 
Numerous studies were conducted to understand the mechanism of $\mathrm{NO}_{\mathrm{x}}$ reduction by ethanol, together with the role of silver [28-33] and alumina [34-36] in nitrogen selectivity. Nevertheless, if the mechanisms of $\mathrm{NO}_{\mathrm{x}}$ reduction with oxygenates compound has been extensively studied, unfortunately, among the more quoted papers [37-39], none directly focus on the reaction selectivity, especially toward $\mathrm{NH}_{3}$ emission. In fact, the proposed mechanisms suggest the transformation of ethanol in surface acetate ions or enolic surface species [38], that furthermore react with $\mathrm{NO}_{2}$ to produce nitromethane which is finally transformed in isocyanate species (-NCO, reaction (1)). The formation of $-\mathrm{NCO}$ species over $\mathrm{Ag} / \mathrm{Al}{ }_{2} \mathrm{O}_{3}$ catalysts is reported in numerous papers when high $\mathrm{NO}_{\mathrm{x}}$ reduction efficiency is achieved [40, 41]. The chemistry of $\mathrm{HNCO}$ formation is well established [37, 41] and involves hydrolysis of HNCO to form $\mathrm{NH}_{3}$, via reaction (2). Thereafter, ammonia is proposed to react with nitrous acid $\left(\mathrm{HNO}_{2}\right)$ to form ammonium nitrite. Ammonium nitrite is thermally unstable above $100^{\circ} \mathrm{C}$, and easily decomposes into $\mathrm{H}_{2} \mathrm{O}$ and $\mathrm{N}_{2}$ (reaction (3)). Isocyanate ions can also react with $\mathrm{NO}_{2}$ [37] at low temperature (e.g. below $200^{\circ} \mathrm{C}$ ). This reaction is however slower than that of $-\mathrm{NCO}$ with water which leads to ammonia formation.

$$
\begin{aligned}
& \mathrm{CH}_{3} \mathrm{NO}_{2}+\mathrm{NO}_{2} \rightarrow \mathrm{HNCO}+\mathrm{H}_{2} \mathrm{O}+\mathrm{NO}_{2} \\
& \mathrm{HNCO}+\mathrm{H}_{2} \mathrm{O} \rightarrow \mathrm{NH}_{3}+\mathrm{CO}_{2} \\
& \mathrm{NH}_{3}+\mathrm{NO}_{2}+\frac{1}{2} \mathrm{H}_{2} \rightarrow \mathrm{NH}_{4} \mathrm{NO}_{2} \rightarrow \mathrm{N}_{2}+2 \mathrm{H}_{2} \mathrm{O}
\end{aligned}
$$

Catalytic active sites of this multi-step reaction mechanism are still controversial and discussed. For instance, many studies deal on the relationship between the structural features of silver species and their catalytic behavior. It appears that ethanol SCR (EtOH-SCR) is catalyzed rather by oxidized silver cations $\left(\mathrm{Ag}^{+}\right)$and/or oxidized silver clusters $\left(\mathrm{Ag}_{\mathrm{n}}{ }^{8+}\right)$ [42-46]. In parallel, metallic silver species was proposed as active in partial oxidation of hydrocarbon (n-dodecane or ethanol), which promote the SCR activity $[47,48]$. Then, an optimal ionic/metallic balance of silver species is proposed in the literature in order to produce efficient EtOH-SCR activity [49]. Also, surface properties of oxides supports are known to influence the dispersion of the chemical species on the catalyst. In particular, the alumina support has been shown to activate $\operatorname{Ag}_{\mathrm{n}}{ }^{\delta+}$ clusters formation on its acid sites [50]. Alumina acidic and basic properties have been shown to play a crucial role in the $\mathrm{SCR}$ of $\mathrm{NO}_{\mathrm{x}}$ with propane, using $\mathrm{Ag} / \mathrm{Al}_{2} \mathrm{O}_{3}$ catalyst [36]. In fact, when ethanol is used as reducer, aluminium coordinatively unsaturated sites (CUS) have been recently reported as involved in $\mathrm{NO}_{\mathrm{x}}$ abatement mechanism [51, 52]. 
Finally, Diesel engine exhaust temperature commonly ranges from $200-250^{\circ} \mathrm{C}$. However, studies of EtOH-SCR with $\mathrm{Ag} / \mathrm{Al}_{2} \mathrm{O}_{3}$ catalysts show that the system activity is limited below $350^{\circ} \mathrm{C}$. The challenge in EtOH-SCR over $\mathrm{Ag} / \mathrm{Al}_{2} \mathrm{O}_{3}$ is then to decrease the working temperature of the catalyst. For instance, Zhang et al. [53] have shown that addition of $\mathrm{H}_{2}$ in the gas mixture, upstream of the catalyst, greatly enhanced the nitrogen formation at $\mathrm{T} \leq 350^{\circ} \mathrm{C}$. However, it implies to introduce or produce $\mathrm{H}_{2}$ on-board.

The objective of this work is to present another alternative to enhance SCR activity at low temperature, i.e. below $350^{\circ} \mathrm{C}$. Working over Ag-based catalyst, the alumina support was modified by zinc introduction. The effects of (i) $\mathrm{Zn}$ content and (ii) the sample calcination temperature have been investigated over the alumina-substituted structure, in order to increase the catalytic activity. Silver content is fixed to $2.0 \mathrm{wt} . \%$, since it has been largely reported in the literature as the optimum loading in EtOH-SCR [27, 54, 55]. Catalysts have been characterized by nitrogen physisorption, X-ray diffraction, transmission electron microscopy, diffuse-reflectance UV/Visible, $\mathrm{H}_{2}$-temperature programmed reduction and Fourier transformed infrared spectroscopy of adsorbed pyridine and $\mathrm{CO}_{2}$, in order to identify active sites.

\section{Experimental}

\subsection{Catalysts Synthesis}

The alumina support was prepared according to an optimized template-assisted sol-gel synthesis route [56]. The aluminum precursor (aluminum sec-butoxide, 97\% Alfa Aesar) was dissolved in 1-butanol at $65^{\circ} \mathrm{C}$, and mechanically stirred until complete dissolution. In parallel, the template [(1-Hexadecyl) trimethylammonium, 98\% Alfa Aesar] was dissolved in 1-butanol. The two solutions were then mixed under gentle stirring at $65^{\circ} \mathrm{C}$. After a homogeneous solution is obtained, a limited amount of water was drop-wise added under vigorous stirring for hydrolysis. The molar composition of the mixture at this step was (in mol.\%): $1 \mathrm{Al}^{3+} / 0.5$ $\mathrm{CTABr} / 10 \mathrm{ButOH} / 2 \mathrm{H}_{2} \mathrm{O}$. Stirring was thereafter maintained for $4 \mathrm{~h}$ at $65^{\circ} \mathrm{C}$ until homogeneity is obtained. The resulting gel was transferred into a Teflon-line autoclave for hydrothermal treatment at $100^{\circ} \mathrm{C}$ for $24 \mathrm{~h}$. After cooling down to room temperature, the solid was recovered by filtration, extensive washing and drying at room temperature for $24 \mathrm{~h}$. Before use for impregnation, the solid was calcined under synthetic dry air at $600^{\circ} \mathrm{C}$ for $4 \mathrm{~h}$ 
(temperature increase rate $=3{ }^{\circ} \mathrm{C} / \mathrm{min}$ ).

The Zn-loaded aluminas supports wee synthesized using the same modus operandi as described above, except that the zinc precursor $\left(\mathrm{Zn}\left(\mathrm{NO}_{3}\right)_{2}, 6 \mathrm{H}_{2} \mathrm{O}, 98 \%\right.$ Sigma-Aldrich) was dissolved in the hydrolysis solution. To ensure a complete dissolution of the precursor, the calculated weight (to achieve the desired $\mathrm{Zn}$-content in the alumina) was dissolved in a hot mixture of 1-butanol and water, which was used, after cooling, as hydrolysis solution. The three Zn-containing alumina supports were synthesized at $\mathrm{Zn} /(\mathrm{Al}+\mathrm{Zn})$ atomic ratio of $0.1,0.2$ and 0.33 . The supports are named $\mathrm{Zn}_{0.1}-\mathrm{Al}_{2} \mathrm{O}_{3}, \mathrm{Zn}_{0.2}-\mathrm{Al}_{2} \mathrm{O}_{3}$ and $\mathrm{Zn}_{0.33}-\mathrm{Al}_{2} \mathrm{O}_{3}$, respectively. In addition, the influence of the calcination temperature on the catalyst properties was studied for the $\mathrm{Zn}_{0.33^{-}}$ $\mathrm{Al}_{2} \mathrm{O}_{3}$ support. So the $\mathrm{Zn}_{0.33}-\mathrm{Al}_{2} \mathrm{O}_{3}$ support was calcined at $800{ }^{\circ} \mathrm{C}\left(\mathrm{Zn}_{0.33}-\mathrm{Al}_{2} \mathrm{O}_{3} \mathrm{C} 800\right)$ then $1000^{\circ} \mathrm{C}\left(\mathrm{Zn}_{0.33}-\mathrm{Al}_{2} \mathrm{O}_{3} \mathrm{C} 1000\right)$, using the same program $\left(3^{\circ} \mathrm{C} / \mathrm{min}\right.$, kept $4 \mathrm{~h}$ before cooling). Table 1 reports the zinc atomic content and the calcination temperature of the different aluminabased supports used in this study.

The Ag impregnation procedure (always at $2 \mathrm{wt} . \% \mathrm{Ag}^{0}$ ) was inspired by the work of Sato et al. [57], using ethanol as solvent. Authors showed that using ethanol instead of water as solvent leads to better EtOH-SCR results, due to an enhancement of the silver particles dispersion. The Ag impregnation was carried out as follow: $980 \mathrm{mg}$ of alumina (or Zn-loaded alumina) was crushed (granules diameter $<100 \mu \mathrm{m}$ ), and was added to $28 \mathrm{~mL}$ of ethanol stirred at room temperature. Two milliliters of an aqueous solution of $\mathrm{AgNO}_{3}(>99 \%$, Sigma-Aldrich $\left[\mathrm{AgNO}_{3}\right]=9.27 \mathrm{~mol} / \mathrm{L}$ ) was slowly added, and stirring was maintained for 30 minutes. The impregnated solid was then heated at $80{ }^{\circ} \mathrm{C}$ for $150 \mathrm{~min}$. Thereafter, the product was recovered by filtration, washed with ethanol, and dryed in oven at $120^{\circ} \mathrm{C}$ during $16 \mathrm{~h}$. Finally, all catalysts wee calcined under synthetic air containing 10 vol.\% of water $\left(600{ }^{\circ} \mathrm{C}\right.$ for $4 \mathrm{~h}$, temperature increase rate $=3{ }^{\circ} \mathrm{C} / \mathrm{min}$ ). The effective $\mathrm{Ag}$ content was measured by ICP, and it is always ranging from $1.91 \mathrm{wt} . \%$ to $1.95 \mathrm{wt} \%$.

\subsection{Physical and structural characterization}

Nitrogen adsorption-desorption isotherms were recorded at $-196{ }^{\circ} \mathrm{C}$, using a Tristar 3000 Micromeritics apparatus. Prior to the measurement, the samples were pretreated at $250{ }^{\circ} \mathrm{C}$ under vacuum for $5 \mathrm{~h}$. The surface area was calculated using the BET model, the pore volume is 
evaluated at $\mathrm{P} / \mathrm{P}_{0}=0.97$, and the pore diameter was measured by using the $\mathrm{BJH}$ model applied to the desorption branch of the isotherms.

Catalysts wee characterized by powder X-ray diffraction using a Bruker D5005 diffractometer equipped with a monochromatized $\mathrm{CuK} \alpha$ radiation $(\lambda=1.5418 \AA$ ) operated at $40 \mathrm{kV}$ and 30 $\mathrm{mA}$. The diffraction patterns wee recorded in the $2 \theta$ value range $15-75^{\circ}$, with a step of $0.04^{\circ}$ $\mathrm{sec}^{-1}$ and a step time of $6 \mathrm{~s}$. Crystalline phases were identified by comparison with ICDD database files. The crystallite size were calculated using Scherrer equation: $D_{h k l}=K \cdot \lambda / \beta \cos \theta$, where $K=$ structure constant $(0.9$ for spherical crystals $) ; \lambda=$ incident ray wavelength $(0.15418$ $\mathrm{nm}) ; \beta=$ peak width at half height after correction for instrumental broadening ( $\mathrm{rad}), \theta=$ Bragg angle. In addition, the crystallite size was also estimated considering the Rietveld formalism.

Transmission Electron Microscopy (TEM) micrographs were recorded on JEOL 2100 instrument (operated at $200 \mathrm{kV}$ with a $\mathrm{LaB}_{6}$ source and equipped with a Gatan Ultra scan camera). EDX spectroscopy was carried out with a Hypernine (Premium) detector (active area: $30 \mathrm{~mm} 2$ ) using the software SM-JED 2300T for data acquisition and treatment. EDX analysis zone was defined on the particle, and it was generally ranging from 5 to $15 \mathrm{~nm}$.

Diffuse reflectance UV-Vis spectra were recorded at room temperature between $200 \mathrm{~nm}$ and $500 \mathrm{~nm}$ on a Varian Cary 5000 spectrometer equipped with a double monochromator. $\mathrm{BaSO}_{4}$ was used as reference. Considering the strong absorbance of the alumina-based supports, the spectrum of bare oxides $\left(\mathrm{Zn}_{\mathrm{x}}-\mathrm{Al}_{2} \mathrm{O}_{3}\right.$, with $\mathrm{x}=0-10-20-33$ at.\%) was subtracted from silver catalyst to focused on the silver species contribution.

\subsection{Surface properties}

The surface acidity of the Ag-impregnated materials was evaluated by IR spectroscopy of adsorbed pyridine. IR spectra were collected with a Nexus Nicolet spectrometer equipped with a DTGS detector (Deuterium TriGlyceride Sulfur) and KBr beam splitter. IR spectra were recorded with a resolution of $4 \mathrm{~cm}^{-1}$ and 64 scans. The presented spectra were normalized to a disc of $10 \mathrm{mg} / \mathrm{cm}^{2}$. After activation at $450{ }^{\circ} \mathrm{C}$, pyridine was adsorbed (200 $\mathrm{Pa}$ at equilibrium) at room temperature. Desorption was performed up to $450{ }^{\circ} \mathrm{C}$, by temperature step of $50{ }^{\circ} \mathrm{C}$. The v8a spectral region was deconvoluated using the peak resolve function of the Omnic software, that allows obtaining the amount of tetrahedral $\mathrm{Al}^{3+}$ (strong Lewis Acid Sites -LAS) and both tetrahedral $\mathrm{Al}^{3+}$ and an octahedral $\mathrm{Al}^{3+}$ (medium to weak LAS). The total amount of 
LAS was determined from the area of the $v 19 \mathrm{~b}$ band, using its molar coefficient $\left(\varepsilon_{v 19 \mathrm{~b}}=1.5 \mathrm{~cm}\right.$ $\left.\mu \mathrm{mol}^{-1}[58]\right)$.

\subsection{Redox properties}

Temperature programmed reduction (TPR) experiments were performed on an Autochem 2920 Micromeritics apparatus equipped with a thermal conductivity detector (TCD). Sample of about $150 \mathrm{mg}$ was placed in a U-shape quartz reactor. Prior to the TPR measurements, the sample was calcined at $550{ }^{\circ} \mathrm{C}$ under $10 \mathrm{vol} . \% \mathrm{O}_{2}$ in Ar flow (temperature increase rate $=10{ }^{\circ} \mathrm{C} / \mathrm{min}-$ step time $=1 \mathrm{~h}$ ). The sample was cooled down to room temperature, and it was purged under Ar flow. The reduction was carried out under 1 vol. $\% \mathrm{H}_{2}$ in Ar flow up to $800{ }^{\circ} \mathrm{C}$ (temperature increase rate $=5{ }^{\circ} \mathrm{C} / \mathrm{min}$ ). TCD signal being sensible to water, an $\mathrm{H}_{2} \mathrm{O}$-trap was added downstream of the reactor, allowing the quantification of the $\mathrm{H}_{2}$ consumed during the TPR experiment.

\subsection{Catalytic activity measurements}

Catalytic tests were performed in a quartz tubular micro-reactor under a flow simulating realistic Diesel engine exhaust conditions (flow composition : 400ppm NO, 500ppm CO, 167ppm $\mathrm{H}_{2}, 1200$ ppm $\mathrm{C}_{2} \mathrm{H}_{5} \mathrm{OH}, 8 \% \mathrm{O}_{2}, 10 \% \mathrm{H}_{2} \mathrm{O}$ and $10 \% \mathrm{CO}_{2}$ balanced in $\mathrm{N}_{2}$ ). Gas flows were controlled using mass-flow controllers (Brooks), except for $\mathrm{H}_{2} \mathrm{O}$ and $\mathrm{C}_{2} \mathrm{H}_{5} \mathrm{OH}$ which were introduced using thermostated saturators. The Gas Hour Space velocity (GHSV, calculated as the volume of feed gas / volume of the catalyst content) was fixed at $150,000 \mathrm{~h}^{-1}$. For each studied temperature $\left(150{ }^{\circ} \mathrm{C}, 250{ }^{\circ} \mathrm{C}, 300{ }^{\circ} \mathrm{C}, 350{ }^{\circ} \mathrm{C}, 450{ }^{\circ} \mathrm{C}\right.$ and $\left.550{ }^{\circ} \mathrm{C}\right)$, the activity of the catalysts was followed until stabilization.

Prior to the analyzers, $\mathrm{H}_{2} \mathrm{O}$ was removed in a condenser cooled at $0{ }^{\circ} \mathrm{C}$. Both $\mathrm{NO}$ and $\mathrm{NO}_{\mathrm{x}}$ concentrations $\left(\mathrm{NO}+\mathrm{NO}_{2}\right)$ are measured by chemiluminescence (Monitor Europe ML9841AS); $\mathrm{CO}$ and $\mathrm{N}_{2} \mathrm{O}$ are quantified by FTIR analyzers (COSMA Beryl 100). In addition, the outlet water was condensed for thirty minutes after stabilization of the activity. The effluent gas mixture passed through a condenser filled with $10 \mathrm{~mL}$ of demineralized water. $\mathrm{NH}_{4}{ }^{+}, \mathrm{NO}_{2}{ }^{-}$ and $\mathrm{NO}_{3}{ }^{-}$concentrations were determined by HPLC (Thermo Finnigan, equipped with an Alltech Universal Cation column $7 \mu \mathrm{m}, 4.6 \times 100 \mathrm{~mm}$ for $\mathrm{NH}_{4}{ }^{+}$; and Agilent Eclipse XDB-C18, $5 \mu \mathrm{m}, 4.6 \mathrm{x} 50 \mathrm{~mm}$ for $\mathrm{NO}_{2}{ }^{-}$and $\mathrm{NO}_{3}{ }^{-}$). $\mathrm{NO}_{2}{ }^{-}$and $\mathrm{NO}_{3}{ }^{-}$wee added to the unconverted $\mathrm{NO}_{\mathrm{x}} . \mathrm{NH}_{4}{ }^{+}$ 
analysis was used to calculate the $\mathrm{NH}_{3}$ selectivity.

Ethanol conversion, as well as $\mathrm{CH}_{3} \mathrm{CHO}, \mathrm{CH}_{3} \mathrm{OH}, \mathrm{CH}_{2} \mathrm{O}, \mathrm{C}_{2} \mathrm{H}_{4}$ and $\mathrm{CH}_{4}$ formation, were measured using a Gas Chromatograph (Varian 3400, Supelco HayeSep R, 60-80 mesh, 1/8'x2000mm) equipped with a FID detector. The $\mathrm{N}_{2}$ selectivity was calculated assuming no other $\mathrm{N}$-compounds than $\mathrm{NO}, \mathrm{NO}_{2}, \mathrm{~N}_{2} \mathrm{O}$ and $\mathrm{NH}_{3}$ are formed. In order to validate the results, every outlet gas $\left(\mathrm{C}_{2} \mathrm{H}_{5} \mathrm{OH}, \mathrm{CH}_{3} \mathrm{CHO}, \mathrm{CH}_{3} \mathrm{OH}, \mathrm{CH}_{2} \mathrm{O}, \mathrm{C}_{2} \mathrm{H}_{4}, \mathrm{CO}, \mathrm{NO}, \mathrm{NO}_{2}, \mathrm{NH}_{3}, \mathrm{~N}_{2} \mathrm{O}\right)$ were regularly checked with an infrared detector (MKS MultiGas 2030 FT-IR).

\section{Results}

\subsection{Physical properties}

\subsubsection{Textural properties}

Table 1 summarizes the textural properties of the supports deduced from the $\mathrm{N}_{2}$ adsorption/desorption isotherms.

Alumina support exhibits a high surface area $\left(263 \mathrm{~m}^{2} / \mathrm{g}\right)$, even after thermal treatment at 600 ${ }^{\circ} \mathrm{C}$ with a feed stream including $10 \mathrm{vol} . \% \mathrm{H}_{2} \mathrm{O}$. A large pore diameter $(9.6 \mathrm{~nm})$ is also obtained. These two parameters are favorable for the dispersion of an active phase, and a use in gas phase reaction. The introduction of $\mathrm{Zn}^{2+}$ in substitution of $\mathrm{Al}^{3+}$ at 10 and 20 at.\% leads to a decrease of the surface area of approximately $22 \%$ at $205-208 \mathrm{~m}^{2} / \mathrm{g}$, associated with a decrease of the pore diameter down to 5.6-5.9 $\mathrm{nm}$. A further increase in $\mathrm{Zn}$ loading (up to 33 at.\% of $\mathrm{Zn}^{3+}$, given the $\mathrm{ZnAl}_{2} \mathrm{O}_{4}$ composition) results in an additional decrease in surface area, which falls to $154 \mathrm{~m}^{2} / \mathrm{g}$, and a slight increase in pore diameter $(7.3 \mathrm{~nm})$.

The increase in calcination temperature for $\mathrm{Zn}_{0.33}-\mathrm{Al}_{2} \mathrm{O}_{3}$ support up to $800{ }^{\circ} \mathrm{C}$ or $1000{ }^{\circ} \mathrm{C}$, results in progressive increase in mean pore diameter and decrease in surface area. At $1000{ }^{\circ} \mathrm{C}$, a surface area of $65 \mathrm{~m}^{2} / \mathrm{g}$ and a pore diameter of $86 \mathrm{~nm}$ are obtained, which is however consistent with a progressive increase in crystal / particle size increase during sintering phenomena. Then, $\mathrm{Zn}^{2+}$ substitution in the alumina structure, as well as the calcination temperature, influence the final textural properties of the material. 
Table 1. Main characteristics and textural properties of the synthesized catalysts

\begin{tabular}{lcccccc}
\hline Catalysts & $\begin{array}{c}\mathrm{Zn} /[\mathrm{Al}+\mathrm{Zn}] \\
(\text { at.\% })\end{array}$ & $\begin{array}{c}\text { Support } \\
\text { calcination } \\
\mathrm{T}\left({ }^{\circ} \mathrm{C}\right)\end{array}$ & $\begin{array}{c}\mathrm{S}_{\mathrm{BET}} \\
\left(\mathrm{m}^{2} / \mathrm{g}\right)\end{array}$ & $\begin{array}{c}\mathrm{V}_{\mathrm{t}} \\
\left(\mathrm{cm}^{3} / \mathrm{g}\right)\end{array}$ & $\begin{array}{c}\mathrm{D}_{\mathrm{p}} \\
(\mathrm{nm})\end{array}$ & $\begin{array}{c}\text { Medium LAS } \\
\text { density } \\
\left(\mu \mathrm{mol} / \mathrm{m}^{2}\right)\end{array}$ \\
\hline $\mathrm{Ag} / \mathrm{Al}_{2} \mathrm{O}_{3}$ & 0 & 600 & 263 & 1.13 & 9.6 & 0.012 \\
$\mathrm{Ag} / \mathrm{Zn}_{0.1}-\mathrm{Al}_{2} \mathrm{O}_{3}$ & 10 & 600 & 205 & 0.38 & 5.9 & 0.018 \\
$\mathrm{Ag} / \mathrm{Zn}_{0.2}-\mathrm{Al}_{2} \mathrm{O}_{3}$ & 20 & 600 & 208 & 0.37 & 5.6 & 0.018 \\
$\mathrm{Ag} / \mathrm{Zn}_{0.33}-\mathrm{Al}_{2} \mathrm{O}_{3}$ & 33 & 600 & 154 & 0.37 & 7.3 & 0.025 \\
$\mathrm{Ag} / \mathrm{Zn}_{0.33}-\mathrm{Al}_{2} \mathrm{O}_{3}$ & 33 & 800 & 117 & 0.32 & 8.0 & 0.016 \\
$\mathrm{C} 800$ & 33 & 1000 & 65 & 0.16 & 8.6 & 0.009 \\
$\mathrm{Ag} / \mathrm{Zn}_{0.33}-\mathrm{Al}_{2} \mathrm{O}_{3}$ & 33 & & & & & \\
$\mathrm{C} 1000$ & & & & & &
\end{tabular}

$\mathrm{Vt}$ is the total pore volume at $\mathrm{P} / \mathrm{P}_{0}=0.97$; $\mathrm{Dp}$ is the pore diameter calculated from the desorption branch of the isotherm using the $\mathrm{BJH}$ method.

a: obtained by integration of $v_{8 \mathrm{a}}$ band at $1617 \mathrm{~cm}^{-1}$ after pyridine evacuation at $450^{\circ} \mathrm{C}$.

\subsubsection{Structure properties}

Crystallinity of the $\mathrm{Ag} / \mathrm{Zn}_{\mathrm{x}}-\mathrm{Al}_{2} \mathrm{O}_{3}$ materials was studied by XRD. Figure $1 \mathrm{~A}$ shows the effect of zinc addition and calcination temperature on the structure of the materials. The $\mathrm{Ag} / \mathrm{Al}_{2} \mathrm{O}_{3}$ material displays the classical $\gamma-\mathrm{Al}_{2} \mathrm{O}_{3}$ structure [ICDD PDF ${ }^{\circ} 00-050-0741(\mathrm{I})$ ]. When $\mathrm{Zn}^{2+}$ is incorporated into the structure, $\mathrm{ZnAl}_{2} \mathrm{O}_{4}$ spinel-type structure reflections are observed [ICDD PDF $\mathrm{n}^{\circ} 01-082-1535$ (C)]. This phase is clearly observed from 10 at.\% $\mathrm{Zn}^{2+}$, with the shift of the $\gamma-\mathrm{Al}_{2} \mathrm{O}_{3}$ reflections to the lower $2 \theta$ values. Nevertheless, we suppose an overlapping of the reflections of the $\mathrm{ZnAl}_{2} \mathrm{O}_{4}$ and the $\gamma-\mathrm{Al}_{2} \mathrm{O}_{3}$ structures until the 33 at. $\%$ of $\mathrm{Zn}^{2+}$ in alumina.

Whatever the $\mathrm{Zn}^{2+}$ content and the calcination temperature, $\mathrm{Ag}$ phase (either oxide or metallic) is not detected on the diffractograms. Nevertheless, the low Ag content in the solids can be responsible for this lack of detection.

Crystallite sizes of the $\mathrm{ZnAl}_{2} \mathrm{O}_{4}$ phase in the $\mathrm{Ag} / \mathrm{Zn}_{\mathrm{x}}-\mathrm{Al}_{2} \mathrm{O}_{3}$ materials (with $\mathrm{x}>0.10$ ) were calculated using the Scherrer equation applied to the $(h k l)$ reflection positioned at $2 \theta=36.83^{\circ}$, which presents the maximum intensity within the spinel structure. $\mathrm{Zn}_{0.1}-\mathrm{Al}_{2} \mathrm{O}_{3}$ sample has been removed due to the strong contribution of the alumina phase on the XRD signal. Figure 1B displays the relationship between the calculated $\mathrm{ZnAl}_{2} \mathrm{O}_{4}$ mean crystallite size and the specific surface area of the catalysts (Table 1). As can be expected, the surface area developed decreases when the crystallite size increases. In addition, the increase in calcination temperature results in an increase of the crystal size from $5.7 \mathrm{~nm}$ (when $\mathrm{Ag} / \mathrm{Zn}_{0.33}-\mathrm{Al}_{2} \mathrm{O}_{3}$ is calcined at $600{ }^{\circ} \mathrm{C}$ ) to 
$13.6 \mathrm{~nm}$ (when calcined at $1000{ }^{\circ} \mathrm{C}$ ). Crystallite sizes were also checked using the Rietveld refinement of XRD patterns, and the results are very similar to those obtained using the Scherrer equation.
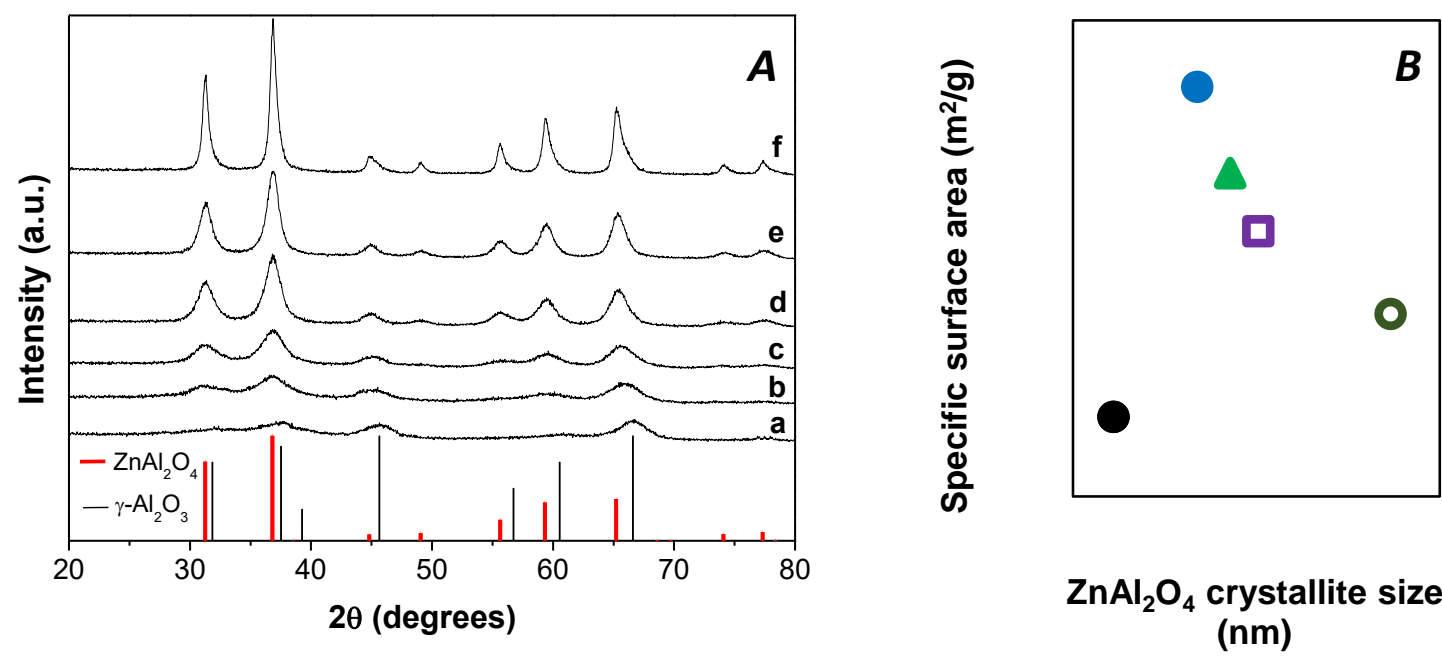

Figure 1. (A): XRD patterns of silvers supported catalysts. (a) $\mathrm{Ag} / \mathrm{Al}_{2} \mathrm{O}_{3}$; (b) $\mathrm{Ag} / \mathrm{Zn} \mathrm{n}_{0.1}-\mathrm{Al}_{2} \mathrm{O}_{3}$; (c) $\mathrm{Ag} / \mathrm{Zn}_{0.2}-\mathrm{Al}_{2} \mathrm{O}_{3}$; (d) $\mathrm{Ag} / \mathrm{Zn}_{0.33}-\mathrm{Al}_{2} \mathrm{O}_{3}$; (e) $\mathrm{Ag} / \mathrm{Zn}_{0.33}-\mathrm{Al}_{2} \mathrm{O}_{3} \mathrm{C} 800$; (f) $\mathrm{Ag} / \mathrm{Zn}_{0.33}-\mathrm{Al}_{2} \mathrm{O}_{3} \mathrm{C} 1000$. (B): Relation between the surface area and the spinel crystallite size. $(\bullet) \mathrm{Ag} / \mathrm{Zn}_{0.2}-\mathrm{Al}_{2} \mathrm{O}_{3}$; ( $\boldsymbol{\Delta}$ ) $\mathrm{Ag} / \mathrm{Zn}_{0.33}-\mathrm{Al}_{2} \mathrm{O}_{3}$; (口) $\mathrm{Ag} / \mathrm{Zn}_{0.33}-\mathrm{Al}_{2} \mathrm{O}_{3} \mathrm{C} 800$; ( $) \mathrm{Ag} / \mathrm{Zn}_{0.33}-\mathrm{Al}_{2} \mathrm{O}_{3} \mathrm{C} 1000$.

\subsubsection{Silver nanoparticles structure and morphology}

\section{Silver reducibility}

Silver reducibility was studied by Temperature-Programmed Reduction (TPR) analysis. Table 2 reports the temperature of the $\mathrm{H}_{2}$ maximum consumption for the different studied catalysts (profiles not shown). It appears that silver supported catalysts show a broad $\mathrm{H}_{2}$ consumption peak, with a maximum spread from $175^{\circ} \mathrm{C}$ to $350^{\circ} \mathrm{C}$ depending on the sample.

Since no significant reduction of alumina or zinc aluminate spinel is expected, this peak is assignable to the reduction of oxidized silver species $\left(\mathrm{Ag}^{+}, \mathrm{Ag}_{\mathrm{n}}{ }^{\delta+}\right.$ and $\left.\mathrm{Ag}_{2} \mathrm{O}\right)$ to metallic ones. Bethke et al. [59] showed that this reduction peak shifts to lower temperature when the average silver particles size increases. Then, this parameter can be used to evaluate the relative silver particles size distribution. The evolution of the reduction peak temperature indicates that the average silver particles size increases with the Zn loading, as well as the calcination temperature for the $\mathrm{Zn}_{0.33}-\mathrm{Al}_{2} \mathrm{O}_{3}$ supported samples. The temperature of the silver reduction peak observed 
for each catalyst is then reported versus their specific area in Figure 2. Based on the work of Bethke et al. [59], the remarkable correlation observed between the specific surface area and the reduction temperature indicates that the average silver particles size depends on zinc loading. So, the average silver particles size increases as well with the atomic percentage of zinc introduces in the alumina structure, and then with the calcination temperature of the support. The higher the $\mathrm{Zn}$ loading, the lower the silver temperature reduction, and so the higher the silver particles size.

Table 2. Silver particles relative number and size over the catalysts, resulting of TPR characterizations.

\begin{tabular}{|c|c|c|c|}
\hline catalyst & $\begin{array}{l}\mathrm{T}_{\text {red }} \\
\left({ }^{\circ} \mathrm{C}\right)\end{array}$ & $\begin{array}{l}\mathrm{H}_{2} \text { consumption } \\
\left(\mu \mathrm{mol.g}^{-1}\right)\end{array}$ & $\begin{array}{c}\text { Metallic silver } \\
\text { content }(\%)\end{array}$ \\
\hline $\mathrm{Ag} / \mathrm{Al}_{2} \mathrm{O}_{3}$ & 319 & 31.5 & 66 \\
\hline $\mathrm{Ag} / \mathrm{Zn}_{0.1} \mathrm{Al}_{2} \mathrm{O}_{3}$ & 280 & 29.7 & 68 \\
\hline $\mathrm{Ag} / \mathrm{Zn}_{0.2}-\mathrm{Al}_{2} \mathrm{O}_{3}$ & 264 & 29.7 & 68 \\
\hline $\mathrm{Ag} / \mathrm{Zn}_{0.33}-\mathrm{Al}_{2} \mathrm{O}_{3}$ & 249 & 29.7 & 68 \\
\hline $\mathrm{Ag} / \mathrm{Zn}_{0.33}-\mathrm{Al}_{2} \mathrm{O}_{3} \mathrm{C} 800$ & 235 & 21.3 & 77 \\
\hline $\mathrm{Ag} / \mathrm{Zn}_{0.33}-\mathrm{Al}_{2} \mathrm{O}_{3} \mathrm{C} 1000$ & 188 & 18.5 & 80 \\
\hline
\end{tabular}

Finally, the hydrogen consumption for each catalyst during the TPR experiments was calculated by integrating the TPR profile curves. Results enable to calculate the ratio of oxidized/metallic silver species for each material, as reported on Table 3, assuming $\operatorname{Ag}^{\mathrm{I}}$ is reduced using the following equations (4) and (5):

$\mathrm{Ag}_{2} \mathrm{O}+\mathrm{H}_{2} \rightarrow 2 \mathrm{Ag}^{0}+\mathrm{H}_{2} \mathrm{O}$

$A l-O^{2-} \cdots A g^{+}+H^{+}\left(\frac{1}{2} H_{2}\right) \rightarrow A g^{0}+A l-O H$

Luo et al. [60] studied the reduction of silver over alumina by TPR, and concluded that $\mathrm{Ag}^{0}$ content was directly proportional to the weight of impregnated silver. In the present work, two thirds of the deposited silver is in metallic state on the alumina support, after the oxidation treatment performed before the TRP test. These results are consistent with the previous work of Musi et al. [61]. Loading $\mathrm{Zn}$ in the alumina structure does not influence this ratio. However, increasing the calcination temperature of the $\mathrm{Zn}_{0.33}-\mathrm{Al}_{2} \mathrm{O}_{3}$ support enhanced the part of metallic silver content, up to $80 \%$ when the support is calcined at $1000^{\circ} \mathrm{C}$. 


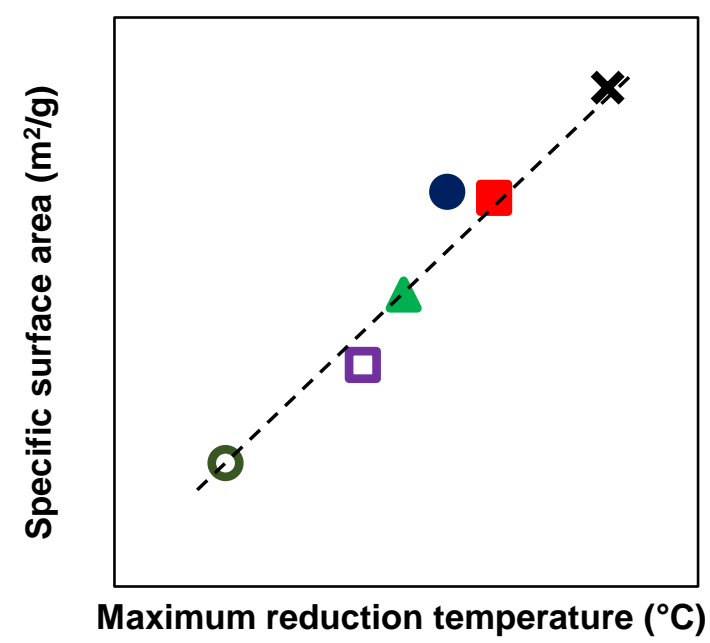

Figure 2. Maximum reduction temperature of the catalysts observed by TPR (silver species), versus their respective surface area. (X) $\mathrm{Ag} / \mathrm{Al}_{2} \mathrm{O}_{3} ;(\boldsymbol{\bullet}) \mathrm{Ag} / \mathrm{Zn}_{0.1}-\mathrm{Al}_{2} \mathrm{O}_{3} ;(\bullet) \mathrm{Ag} / \mathrm{Zn}_{0.2}-\mathrm{Al}_{2} \mathrm{O}_{3}$; ( $\mathbf{\Delta}) \mathrm{Ag} / \mathrm{Zn}_{0.33}-\mathrm{Al}_{2} \mathrm{O}_{3}$; (口) $\mathrm{Ag} / \mathrm{Zn}_{0.33}-\mathrm{Al}_{2} \mathrm{O}_{3} \mathrm{C} 800$; ( ( ) $\mathrm{Ag} / \mathrm{Zn}_{0.33}-\mathrm{Al}_{2} \mathrm{O}_{3} \mathrm{C} 1000$.

Table 3. Effect of zinc addition over the ethanol and $\mathrm{NO}_{\mathrm{x}}$ conversion at $300^{\circ} \mathrm{C}$ and $450^{\circ} \mathrm{C}$. Comparison between the supports and the corresponding silver supported catalysts.

\begin{tabular}{|c|c|c|c|c|}
\hline \multirow[t]{2}{*}{ Catalysts } & \multicolumn{2}{|c|}{ Conv. EtOH (\%) } & \multicolumn{2}{|c|}{ Conv. $N O_{x}(\%)$} \\
\hline & $300{ }^{\circ} \mathrm{C}$ & $450^{\circ} \mathrm{C}$ & $300^{\circ} \mathrm{C}$ & $450^{\circ} \mathrm{C}$ \\
\hline $\mathrm{Al}_{2} \mathrm{O}_{3}$ & 30 & 100 & 2 & 21 \\
\hline $\mathrm{Ag} / \mathrm{Al}_{2} \mathrm{O}_{3}$ & 95 & 100 & 74 & 100 \\
\hline $\mathrm{Zn}_{0.1}-\mathrm{Al}_{2} \mathrm{O}_{3}$ & 27 & 100 & 1 & 10 \\
\hline $\mathrm{Ag} / \mathrm{Zn}_{0.1}-\mathrm{Al}_{2} \mathrm{O}_{3}$ & 76 & 100 & 51 & 98 \\
\hline $\mathrm{Zn}_{0.2}-\mathrm{Al}_{2} \mathrm{O}_{3}$ & 26 & 100 & 0 & 22 \\
\hline $\mathrm{Ag} / \mathrm{Zn}_{0.2}-\mathrm{Al}_{2} \mathrm{O}_{3}$ & 99 & 100 & 86 & 99 \\
\hline $\mathrm{Zn}_{0.33}-\mathrm{Al}_{2} \mathrm{O}_{3}$ & 25 & 100 & 2 & 16 \\
\hline $\mathrm{Ag} / \mathrm{Zn}_{0.33}-\mathrm{Al}_{2} \mathrm{O}_{3}$ & 100 & 100 & 87 & 100 \\
\hline $\mathrm{Zn}_{0.33}-\mathrm{Al}_{2} \mathrm{O}_{3} \mathrm{C} 800$ & 28 & 100 & 2 & 22 \\
\hline $\mathrm{Ag} / \mathrm{Zn}_{0.33}-\mathrm{Al}_{2} \mathrm{O}_{3} \mathrm{C800}$ & 100 & 100 & 100 & 100 \\
\hline $\mathrm{Zn}_{0.33}-\mathrm{Al}_{2} \mathrm{O}_{3} \mathrm{C} 1000$ & 17 & 100 & 2 & 24 \\
\hline $\mathrm{Ag} / \mathrm{Zn}_{0.33}-\mathrm{Al}_{2} \mathrm{O}_{3} \mathrm{C} 1000$ & 65 & 100 & 7 & 56 \\
\hline
\end{tabular}


To conclude, loading zinc in the alumina structure raises the average size of the impregnated silver particles, which are reducible at lower temperature. It does not change the ratio oxidized/metallic silver phase, contrary to raising the calcination temperature of the support to $800^{\circ} \mathrm{C}$ or $1000^{\circ} \mathrm{C}$. In the next part of this work, metallic silver particles were characterized by TEM experiments, whereas UV-Vis analysis provided information on the nature of the particles.

\section{Silver morphology}

The evolution of the silver nanoparticle morphology and size with the $\mathrm{Zn}^{2+}$ content is presented in Figure 3. Firstly, it is noteworthy that silver particles observed by TEM over the catalysts surface are mostly metallic. Indeed, particles present inter-reticular distances of $d \approx 2.3 \AA$. Some of them show two distances, $\mathrm{d} \approx 2.3 \AA$ and $\mathrm{d} \approx 2 \AA$, with an angle of $70^{\circ}$ between them. These parameters are characteristics of $\mathrm{Ag}^{0}$ in face centered cubic configuration (ICCD PDF $\mathrm{n}^{\circ} 01$ 089-3722).

The $\mathrm{Ag} / \mathrm{Al}_{2} \mathrm{O}_{3}$ sample presents the lower silver particles size distribution, most of the particles ranging below $10 \mathrm{~nm}$. The $\mathrm{Zn}^{2+}$ insertion in the alumina matrix leads to an increase in the silver particle size. Starting from $\mathrm{Zn}=10$ at.\%, larger silver particles are observed, even if most of the particles present size below $10 \mathrm{~nm}$, as observed for the $\mathrm{Ag} / \mathrm{Al}_{2} \mathrm{O}_{3}$ catalyst. The presence of very large particles and the formation of aggregates are however clearly observed on the $\mathrm{Ag} / \mathrm{Zn}_{0.33}-\mathrm{Al}_{2} \mathrm{O}_{3}$ material. These large particles are clearly observed in Figure $3(\mathrm{G})$, and the formation of aggregates is depicted in Figure 3(H). While the mean elementary particle size seems to increase over the $\mathrm{Zn}$-doped supports, it is always possible to observe small particles, even at high $\mathrm{Zn}^{2+}$ content [see Figure 3(I)]. 

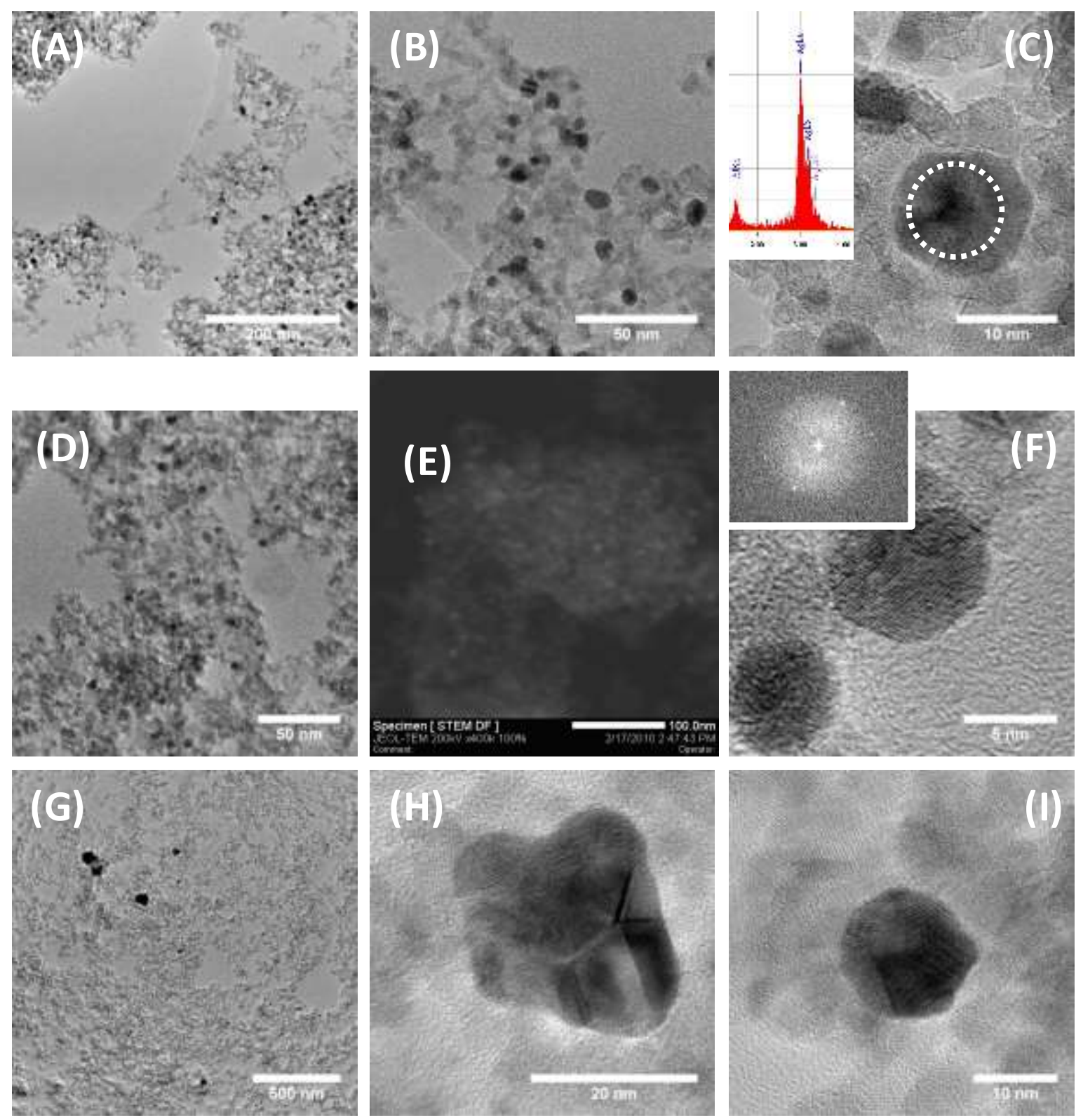

Figure 3. Representative TEM images obtained for $(\mathrm{A}, \mathrm{B}, \mathrm{C}) \mathrm{Ag} / \mathrm{Al}_{2} \mathrm{O}_{3}$ [inset: EDX spectrum recorded on the defined zone in (c)]; (D,E,F) $\mathrm{Ag} / \mathrm{Zn}_{0.10}-\mathrm{Al}_{2} \mathrm{O}_{3}[(\mathrm{E})$ is the HAADF image; (F) inset is the FFT of the $5 \mathrm{~nm}$ particle]; $(\mathrm{G}, \mathrm{H}, \mathrm{I})$ TEM images at different magnifications for $\mathrm{Ag} / \mathrm{Zn}_{0.33}-\mathrm{Al}_{2} \mathrm{O}_{3}$. All samples were calcined at $600^{\circ} \mathrm{C}$. 

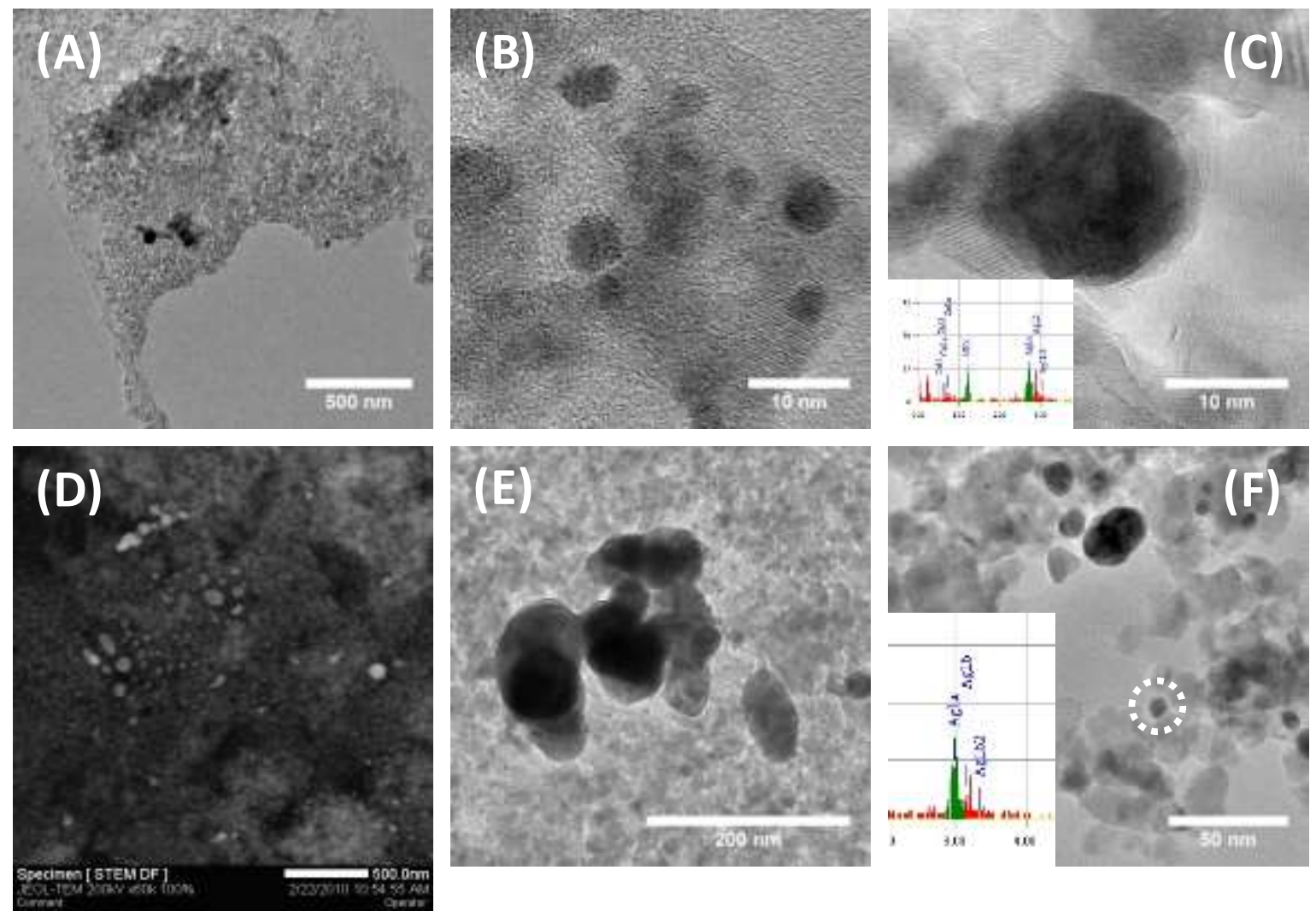

Figure 4. Representative TEM images obtained for $\mathrm{Ag} / \mathrm{Zn} \mathrm{n}_{0.33}-\mathrm{Al}_{2} \mathrm{O}_{3}$ after calcination at $800{ }^{\circ} \mathrm{C}$ $(\mathrm{A}, \mathrm{B}, \mathrm{C})$ and $1000^{\circ} \mathrm{C}(\mathrm{D}, \mathrm{E}, \mathrm{F})$.

The effect of the calcination temperature on the silver particle size and repartition in the support is clearly observed in Figure 4. Indeed, the increase in calcination temperature from $600{ }^{\circ} \mathrm{C}$ [Figure $3(\mathrm{G}, \mathrm{H}, \mathrm{I})$ ] to $800{ }^{\circ} \mathrm{C}$ [Figure $4(\mathrm{~A}, \mathrm{~B}, \mathrm{C})$ ] seems to induce only a slight increase in particle size. Indeed, the formation of large particle is always observed [Figure 4(A)], but some zone of the support seems to be enriched in silver.

The presence of small particles (below $10 \mathrm{~nm}$ ) is however always observed [Figure 4(B,C)]. After calcination at $1000{ }^{\circ} \mathrm{C}$, the $\mathrm{Ag}$ particle and aggregate sizes are however largely increased, as it can be observed on the HAADF image [Figure 4(D)]. Indeed, while the Ag particles are difficult to observe by HAADF after calcinations at $600^{\circ} \mathrm{C}$ [Figure $3(\mathrm{E})$ for $\mathrm{Ag} / \mathrm{Zn}_{0.10}-\mathrm{Al}_{2} \mathrm{O}_{3}$; similar images were however obtained for all materials calcined at the same temperature], the Ag particles are clearly observed after calcination at $1000{ }^{\circ} \mathrm{C}$. In addition, direct TEM observation allows the easy detection of the large particles, or aggregates of particles [Figure 4(E,F)]. Nevertheless, some small particles $(\sim 5-10 \mathrm{~nm})$ remain observable by TEM [Figure $4(\mathrm{~F})]$. 
TEM analysis should be used with caution when studying silver-based catalysts due to the possible dissolution/precipitation, and formation of large particles, during sample preparation for TEM analysis. Nevertheless, the contribution of this step should be logically considered as similar for all materials. Then, TEM observation is suggesting that both zinc introduction and raising the calcination temperature result in an increase in the mean silver metallic particle size, especially when the calcination temperature reached $1000{ }^{\circ} \mathrm{C}$. These results are consistent with the TPR study, which showed that loading zinc in the alumina structure raises the average size of the impregnated silver particles.

\section{Silver state}

UV/Visible is used to evaluate the state of silver supported nanoparticles on the different supports. The corresponding UV-Vis spectra are presented in Figure 5, completed by attributions of the UV-Visible bands based on the literature data. In order to focus on silver absorption bands, the support contribution spectrum was subtracted for each catalyst. Figure $5 \mathrm{~A}$ shows the influence of the zinc loading inside the alumina structure, whereas Figure $5 \mathrm{~B}$ highlights the calcination temperature impact on $\mathrm{Ag} / \mathrm{Zn}_{0.33}-\mathrm{Al}_{2} \mathrm{O}_{3}$ properties.

It is largely reported in the literature that UV-Vis spectra cannot provide quantitative data of silver state on alumina, essentially due to (i) the high extinction coefficients for $\mathrm{Ag}_{\mathrm{n}}{ }^{\delta+}$ and $\mathrm{Ag}_{\mathrm{n}}{ }^{0}$ clusters compared to that of $\mathrm{Ag}^{+}$ions and (ii) to the fact that some types of $\mathrm{Ag}^{+}$ions are not detectable. However, the deconvolution into Gaussian subbands of UV-Vis spectra can be performed to obtain, by integrated the peak area, an underestimate percentage of $\mathrm{Ag}^{+}$ions compared to $\mathrm{Ag}_{\mathrm{n}}{ }^{\delta+}$ and $\mathrm{Ag}_{\mathrm{n}}{ }^{0}$ clusters. Results are reported in Figure 6 and enable to assess the distribution of the detectable silver species on the whole materials. In fact, peaks at about 200$230 \mathrm{~nm}$ and 250-260 $\mathrm{nm}$ are assigned to highly dispersed silver ions $\left(\mathrm{Ag}^{+}\right)$and oxidized silver clusters $\left(\operatorname{Ag}_{\mathrm{n}}{ }^{\delta+}\right)$, respectively. Bands located at $290 \mathrm{~nm}$ and $350 \mathrm{~nm}$ are attributed to metallic silver cluster $\left(\operatorname{Ag}_{\mathrm{n}}{ }^{0}\right)$. An approximation of the silver state distribution over the catalysts is then obtained. Figure 6 presents the contribution of each silver species detected by UV-Visible, versus the percentage of zinc added into the alumina network (Figure 6A), and the calcination temperature of $\mathrm{Zn}_{0.33}-\mathrm{Al}_{2} \mathrm{O}_{3}$ (Figure 6B). 

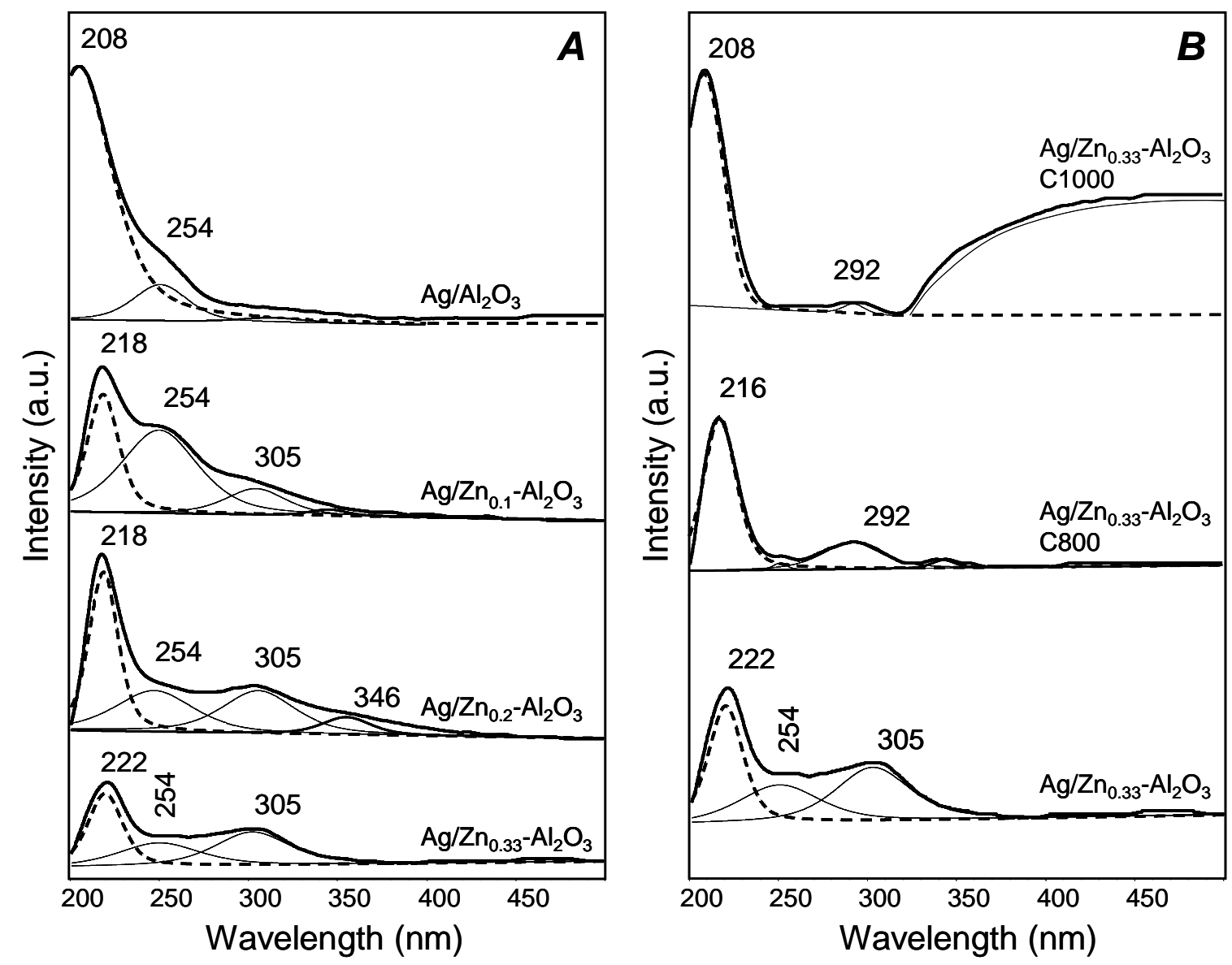

\begin{tabular}{lccccc}
\hline $\mathbf{v}(\mathbf{n m})$ & $200-230$ & $250-260$ & $290-305$ & 350 & $\geq 390$ \\
\hline Ag species & $\mathrm{Ag}^{+}$ions & $\begin{array}{c}\mathrm{Ag}_{\mathrm{n}}{ }^{8+} \text { clusters } \\
\mathrm{n} \leq 8\end{array}$ & metallic $\mathrm{Ag}^{0}$ & $\begin{array}{c}\text { metallic } \mathrm{Ag}_{\mathrm{n}}{ }^{0} \\
\text { clusters, } \mathrm{n} \leq 8\end{array}$ & $\begin{array}{c}\text { metallic } \mathrm{Ag}_{\mathrm{n}}{ }^{0} \\
\text { clusters, } \mathrm{n} \geq 10\end{array}$ \\
\hline References & {$[59,62-65]$} & {$[66-71]$} & {$[64]$} & {$[66-69,72]$} & {$[32,64,70]$} \\
\hline
\end{tabular}

Figure 5. Ex-situ UV-Visible spectra and deconvolution of the silver supported catalysts. (A) Influence of the zinc loading; (B) Influence of the calcination temperature.

Results shows that zinc loading into the alumina network strongly impacts the silver state of the catalysts. In fact, Figure $6 \mathrm{~A}$ shows that $\mathrm{Zn}$ incorporation $(\mathrm{x}=0.1 \%, 0.2 \%$ and $0.3 \%)$ leads to decrease by more than half the contribution of the $\mathrm{Ag}^{+}$ions band $(\lambda<250 \mathrm{~nm})$. In parallel, increases of the contribution of oxidized $\mathrm{Ag}_{\mathrm{n}}{ }^{{ }^{+}}$cluster (band at $\lambda=250-260 \mathrm{~nm}$ ) and $\mathrm{Ag}_{\mathrm{n}}{ }^{0}$ metallic (band at $\sim 300 \mathrm{~nm}$ ) are observed. A slight increase of the metallic $\operatorname{Ag}_{\mathrm{n}}{ }^{0}$ clusters with $\mathrm{n} \geq 8(\lambda=350 \mathrm{~nm})$ is observed when $\mathrm{x}=0.1 \%$ and $0.2 \%$. These results suggest that the addition of zinc into the alumina structure favored the sintering of the dispersed $\mathrm{Ag}^{+}$ions, obtained at the end of the silver impregnation step, into silver oxidized $\left(\mathrm{Ag}_{\mathrm{n}}{ }^{\delta+}\right)$ clusters and metallic $\left(\mathrm{Ag}^{0}\right)$ species. 


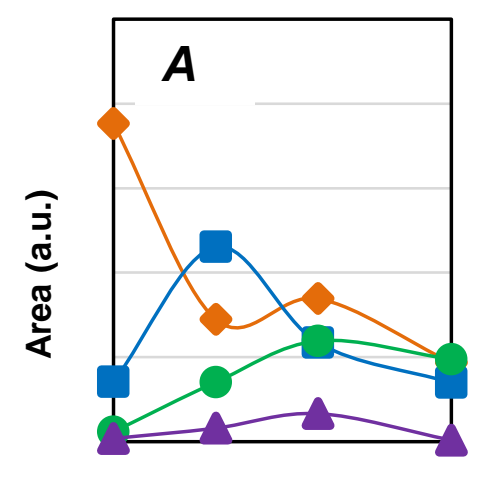

Ratio of zinc $x$ in $\mathrm{Ag} / \mathrm{Zn}_{\mathrm{x}}-\mathrm{Al}_{2} \mathrm{O}_{3}(\%)$

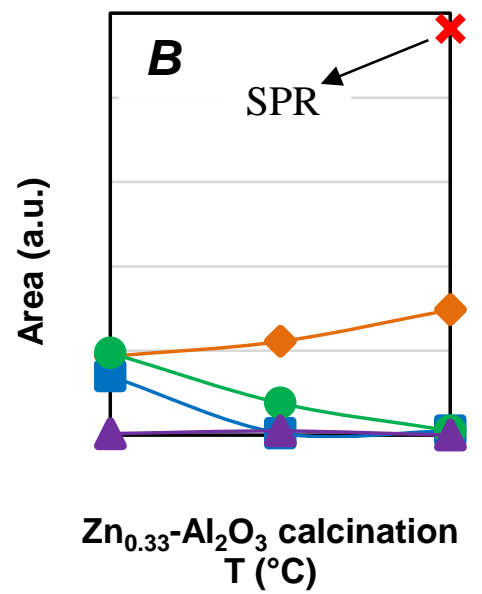

$\mathrm{T}\left({ }^{\circ} \mathrm{C}\right)$

Figure 6. Deconvoluted area of silver species obtained in UV-Visible. (A) Influence of zinc addition; (B) Influence of the calcination temperature. ( $) \mathrm{Ag}^{+}$ions; ( $\left.\bullet\right) \mathrm{Ag}_{\mathrm{n}}{ }^{\delta+} ;(\bullet)$ metallic $\mathrm{Ag}^{0} ;(\boldsymbol{\Delta})$ metallic $\mathrm{Ag}_{\mathrm{n}}{ }^{0}$ clusters, $\mathrm{n} \leq 8 ;(\mathbf{X})$ Metallic $\mathrm{Ag}_{\mathrm{n}}{ }^{0}$ clusters, $\mathrm{n} \geq 10$ (SPR phenomena).

Figure $6 \mathrm{~B}$ shows that the increase in calcination temperature (case of $\mathrm{Ag} / \mathrm{Zn}_{0.33}-\mathrm{Al}_{2} \mathrm{O}_{3}$ ) to $800^{\circ} \mathrm{C}$ and then $1000^{\circ} \mathrm{C}$ leads to a diminution of the amount of $\operatorname{Ag}_{\mathrm{n}}{ }^{\delta+}$ clusters $(\lambda=250-260 \mathrm{~nm})$ and metallic $\mathrm{Ag}^{0}$ (band at $\sim 300 \mathrm{~nm}$ ), while highly dispersed silver ions $\left(\mathrm{Ag}^{+}, \lambda<250 \mathrm{~nm}\right.$ ) are enhanced compared to catalysts calcined at $600^{\circ} \mathrm{C}$. Increasing the calcination temperature up to $1000^{\circ} \mathrm{C}$ enables the observation of the Surface Plasmon Resonance (SPR) phenomenon, linked to nanoparticles or aggregates of metallic silver $\mathrm{Ag}^{0}$ larger than $10 \mathrm{~nm}(\lambda>390 \mathrm{~nm})[35,57,64]$. It is noteworthy that these metallic particles, responsible for the SPR phenomenon, do not contribute to the metallic $\mathrm{Ag}^{0}$ band at around $300 \mathrm{~nm}$. Compared with TEM results, it is likely that this band ( $\lambda$ around $300 \mathrm{~nm}$ ) is characteristic of $\mathrm{Ag}^{0}$ particles larger than $100 \mathrm{~nm}$, which are not observed with $\mathrm{Ag} / \mathrm{Zn}_{0.33}-\mathrm{Al}_{2} \mathrm{O}_{3} \mathrm{C} 1000$, contrary to $\mathrm{Ag} / \mathrm{Zn}_{\mathrm{x}}-\mathrm{Al}_{2} \mathrm{O}_{3}(\mathrm{x}=0.1 ; 0.2 ; 0.33)$ and $\mathrm{Ag} / \mathrm{Zn}_{0.33}-\mathrm{Al}_{2} \mathrm{O}_{3} \mathrm{C} 800$. It implies that SPR phenomenon is rather linked to silver nanoparticles in the $10-100 \mathrm{~nm}$ range.

Finally, these spectra confirms that all samples contain oxidized silver species $\left(\mathrm{Ag}^{+}, \mathrm{Ag}_{\mathrm{n}}{ }^{\mathrm{\delta}}\right)$ and metallic silver species $\left(\mathrm{Ag}_{\mathrm{n}}, \mathrm{Ag}^{0}\right)$, with repartition depending on the support. Zinc incorporation to the alumina-based network leads to enhance the contribution of oxidized $\operatorname{Ag}_{n}{ }^{\delta+}$ clusters, but also metallic silver. Nevertheless, no important modification of silver state is denoted in regards of $\mathrm{Zn}$ loading (i.e. $10 \%, 20 \%$ or $33 \%$ ). In parallel, increasing the calcination temperature of the support from $600^{\circ} \mathrm{C}$ to $800^{\circ} \mathrm{C}$ then $1000^{\circ} \mathrm{C}$ enables to maintain the amount of silver cationic species $\left(\mathrm{Ag}^{+}\right)$. 


\subsection{Acid-base surface properties}

In this part, the effects of zinc addition over the surface properties of the catalysts are studied. Acid-base properties, as well as residual $\mathrm{OH}$ groups of alumina-based supports, were investigated using pyridine and $\mathrm{CO}_{2}$ adsorption monitored by IR spectroscopy.

The $\mathrm{CO}_{2}$ adsorption experiments show similar carbonate species in nature and in number on each material, denoting that zinc addition has little influence on the basic characters of the host alumina (spectra not shown).

Figure 7 compares the IR spectra in the $\mathrm{OH}$ stretching region of the Ag catalysts supported over pure alumina and $\mathrm{Zn}$ doped alumina supports, after outgassing at $450^{\circ} \mathrm{C}$. The IR spectrum of the reference $\mathrm{Al}_{2} \mathrm{O}_{3}$ catalyst is consistent with that previously reported in the literature [73]. Results show different types of $\mathrm{OH}$ groups on alumina, displaying bands at 3788, 3770, 3727 and $3670 \mathrm{~cm}^{-1}$. The spectra of $\mathrm{Zn}$ doped samples are significantly different for the free $\mathrm{OH}$ groups.

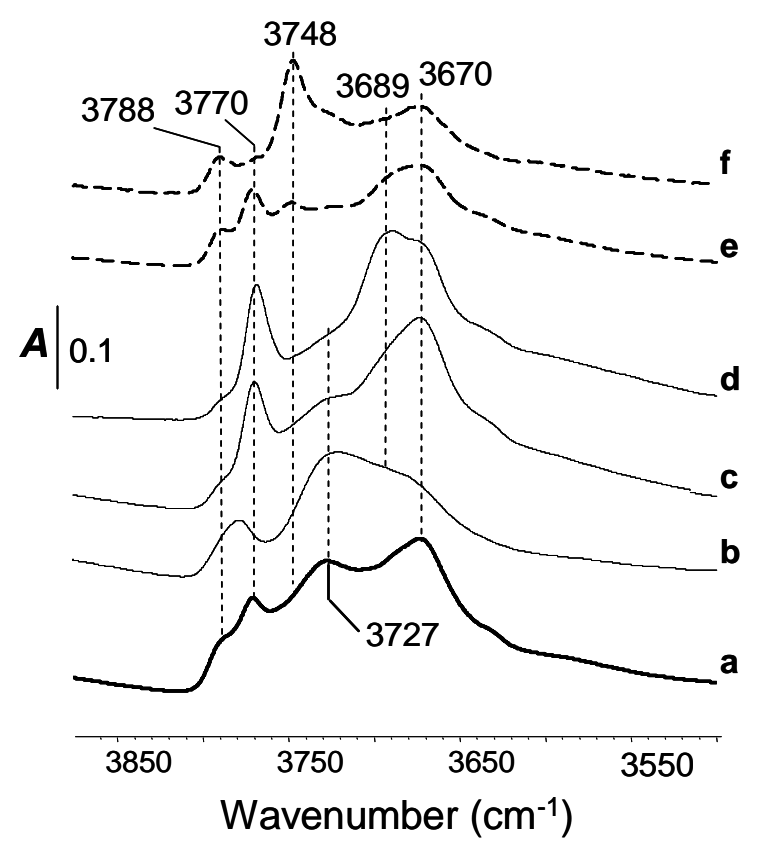

Figure 7. IR spectra in the $v_{(\mathrm{OH})}$ region of alumina and zinc-doped alumina catalysts, activated at $450{ }^{\circ} \mathrm{C}$. (a) $\mathrm{Ag} / \mathrm{Al}_{2} \mathrm{O}_{3}$; (b) $\mathrm{Ag} / \mathrm{Zn}_{0.1}-\mathrm{Al}_{2} \mathrm{O}_{3}$; (c) $\mathrm{Ag} / \mathrm{Zn}_{0.2}-\mathrm{Al}_{2} \mathrm{O}_{3}$; (d) $\mathrm{Ag} / \mathrm{Zn}_{0.33}-\mathrm{Al}_{2} \mathrm{O}_{3}$; (e) $\mathrm{Ag} / \mathrm{Zn}_{0.33} \mathrm{Al}_{2} \mathrm{O}_{3} \mathrm{C} 800$; (f) $\mathrm{Ag} / \mathrm{Zn}_{0.33}-\mathrm{Al}_{2} \mathrm{O}_{3} \mathrm{C} 1000$. 
The band at $3770 \mathrm{~cm}^{-1}$ on $\mathrm{Ag} / \mathrm{Al}_{2} \mathrm{O}_{3}$ catalyst is assigned to the Type Ia of the Tsyganenko model $[74,75]$. This type is attributed to $\mathrm{OH}$ groups coordinated to one $\mathrm{Al}^{3+}$ in tetrahedral coordination, at the surface layers of alumina. These $\mathrm{OH}$ groups are the most affected by the addition of zinc in the alumina structure: the higher the Zn loading, the higher the intensity of the band at $3770 \mathrm{~cm}^{-1}$. In contrast, this band decreases when the calcination temperature of $\mathrm{Ag} / \mathrm{Zn}_{0.33} \mathrm{Al}_{2} \mathrm{O}_{3}$ is raised to $800^{\circ} \mathrm{C}$ then $1000^{\circ} \mathrm{C}$ (dotted lines in Figure 7).

IR spectra of catalysts loaded with $20 \%$ and $33 \%$ of zinc, along with $\mathrm{Ag} / \mathrm{Zn}_{0.33} \mathrm{Al}_{2} \mathrm{O}_{3} \mathrm{C} 800$, display a new band detected at $3689 \mathrm{~cm}^{-1}$. $\mathrm{Ag} / \mathrm{Zn}_{0.22} \mathrm{Al}_{2} \mathrm{O}_{3} \mathrm{C} 800$ and $\mathrm{Ag} / \mathrm{Zn}_{0.33}-\mathrm{Al}_{2} \mathrm{O}_{3} \mathrm{C} 1000$ catalysts also exhibit another band at $3748 \mathrm{~cm}^{-1}$, particularly intensive for the lattest catalyst. It is noteworthy that $\mathrm{Ag} / \mathrm{Zn}_{0.33}-\mathrm{Al}_{2} \mathrm{O}_{3} \mathrm{C} 1000$ spectrum has similarities with other alumina spinel structure based on zinc [76], magnesium [77] or cobalt [78]. Finally, Type III acidic OH groups $\left(v_{\mathrm{OH}}\right.$ at $\left.3670 \mathrm{~cm}^{-1}\right)$ are not significantly affected by the zinc addition.

In conclusion, the differences in the features of the catalysts IR spectra can be related to their modifications with $\mathrm{Zn}$. Indeed, $\gamma-\mathrm{Al}_{2} \mathrm{O}_{3}$ and $\mathrm{Zn}_{\mathrm{x}}-\mathrm{Al}_{2} \mathrm{O}_{3}(\mathrm{x}=0.1 ; 0.2 ; 0.33)$ materials present a spinel-type structure. But zinc aluminate samples have rather a normal structure [79] whereas alumina is a defective spinel. Based on these results, it seems that the spinel structure is formed starting from 10 at.\% Zn loading, in accordance with the XRD analysis.

The surface acidity was determined by IR spectroscopy of adsorbed pyridine, which is one of the most largely used basic probe molecules for surface acidity characterization [80]. Due to the nitrogen electron lone pair, pyridine interacts with acidic centers in a specific way to form (i) the pyridinium ion on protonic sites $\left(\mathrm{PyH}^{+}\right)$and (ii) coordinated species on Lewis acid sites (PyL), giving rise to $v_{8 \mathrm{a}}, v_{8 \mathrm{~b}}, v_{19 \mathrm{a}}$ and $v_{19 \mathrm{~b}}$ ring vibration modes. Pyridine (200 Pa at equilibrium) was adsorbed at room temperature, and then desorbed by temperature steps of $50^{\circ} \mathrm{C}$ up to $450^{\circ} \mathrm{C}$.

Figure 8 presents the IR spectra of the catalysts when pyridine is evacuated at $200^{\circ} \mathrm{C}$. In such conditions, only pyridine coordinated on Lewis acid sites (LAS) is observed. No IR bands assigned to pyridinium ion were detected, as expected on alumina, which does not exhibit $\mathrm{OH}$ groups strong enough to protonate the pyridine. Characteristic IR absorption bands are displayed at $1623,1617,1575,1495$ and $1452 \mathrm{~cm}^{-1}$ on the reference $\mathrm{Al}_{2} \mathrm{O}_{3}$ support (Figure 8, spectrum (a)), as well as on Zn doped materials (spectra (b) to (f)). 


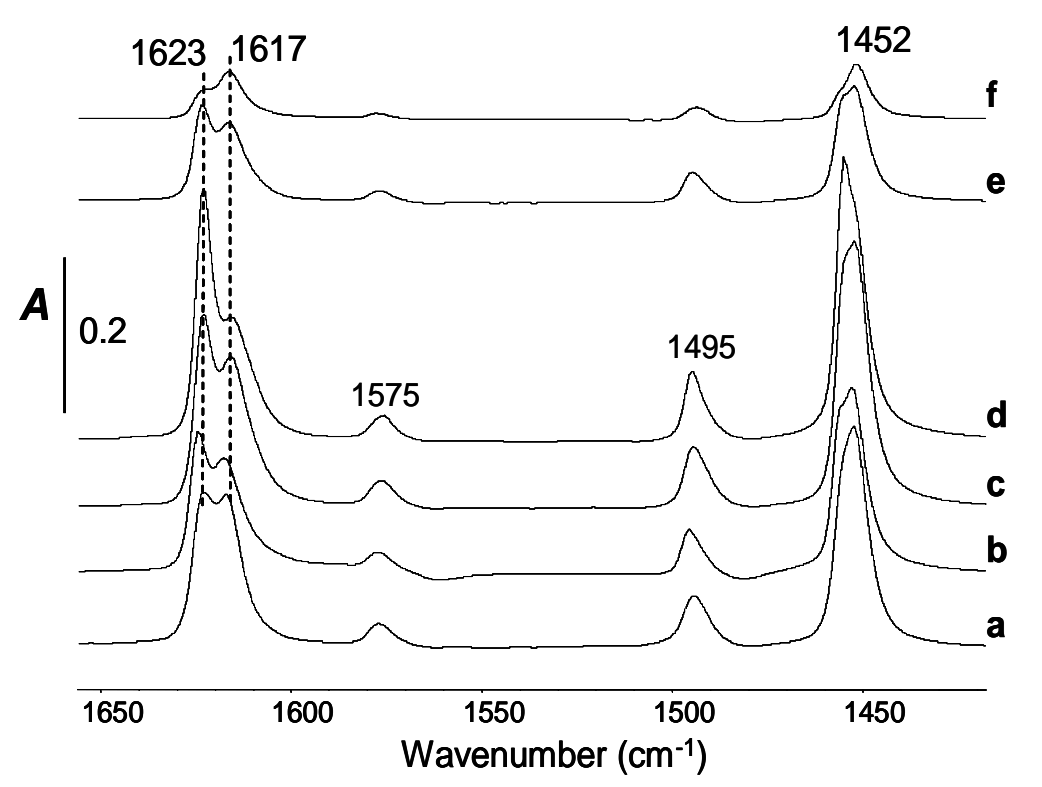

Figure 8. IR difference spectra of pyridine desorbed at $200{ }^{\circ} \mathrm{C}$. (a) $\mathrm{Ag} / \mathrm{Al}_{2} \mathrm{O}_{3}$; (b) $\mathrm{Ag} / \mathrm{Zn}_{0.1^{-}}$ $\mathrm{Al}_{2} \mathrm{O}_{3}$; (c) $\mathrm{Ag} / \mathrm{Zn}_{0.2}-\mathrm{Al}_{2} \mathrm{O}_{3}$; (d) $\mathrm{Ag} / \mathrm{Zn}_{0.33}-\mathrm{Al}_{2} \mathrm{O}_{3}$; (e) $\mathrm{Ag} / \mathrm{Zn}_{0.33}-\mathrm{Al}_{2} \mathrm{O}_{3} \mathrm{C} 800$; (f) $\mathrm{Ag} / \mathrm{Zn}_{0.33}-\mathrm{Al}_{2} \mathrm{O}_{3}$ $\mathrm{C} 1000$.

In order to study the influence of zinc incorporation over Lewis Acid Sites (LAS), two adsorption modes can be assessed. The first one $\left(v_{8 a}\right)$ enables the description of the LAS strength, whereas the second one $\left(v_{19 b}\right)$ allows the quantification of the total amount of coordinated pyridine, obtained from the surface area of its absorption band using its molar

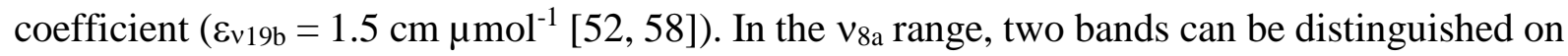
the reference alumina (Figure 7, spectrum a) at $1623 \mathrm{~cm}^{-1}$ and $1617 \mathrm{~cm}^{-1}$, assigned to pyridine coordinated to tetrahedral $\mathrm{Al}^{3+}$ (strong LAS) and to both tetrahedral and octahedral $\mathrm{Al}^{3+}$ (medium to weak LAS), respectively. Influence of the zinc addition in the alumina structure over the LAS strength was assessed using the area of $v_{19 b}$ band (total LAS), whereas the $v_{8 a}$ deconvolution enables to obtain the distribution, in $\mu \mathrm{mol} . \mathrm{g}^{-1}$, of pyridine coordinated to strong and medium LAS, as explained in the experimental part. Total and strong LAS amount was reported in function of pyridine temperature evacuation in Figure 9A and 9B respectively. It appears that total LAS concentration is not strongly affected by $\mathrm{Zn}$ loading. To the opposite, rising the calcination temperature of the support $\left(\mathrm{Ag} / \mathrm{Zn}_{0.33}-\mathrm{Al}_{2} \mathrm{O}_{3} \mathrm{C} 800\right.$ and $\mathrm{Ag} / \mathrm{Zn}_{0.33}-\mathrm{Al}_{2} \mathrm{O}_{3}$ C1000 materials) decreases the total amount of LAS. Concerning the distribution of coordinative unsaturated sites (Figure 9B), both the $\mathrm{Zn}$ incorporation in the alumina network and the temperature calcination strongly impact the concentration of strong LAS. In fact, it appears that the higher the $\mathrm{Zn}$ loading, the higher the strong LAS amount. Raising the 
calcination temperature from $600^{\circ} \mathrm{C}$ to $800^{\circ} \mathrm{C}$ and $1000^{\circ} \mathrm{C}$ leads to decrease the concentration of strong LAS. It is worth noting that the $\mathrm{Ag} / \mathrm{Zn}_{0.33}-\mathrm{Al}_{2} \mathrm{O}_{3} \mathrm{C} 800$ catalyst presents homogeneous strong LAS population. To conclude, doping the alumina host support by $\mathrm{Zn}$ leads to modify the $\mathrm{Al}^{3+}{ }_{\mathrm{IV}} / \mathrm{Al}^{3+}{ }_{\mathrm{VI}}$ coordinative unsaturated sites ratio.
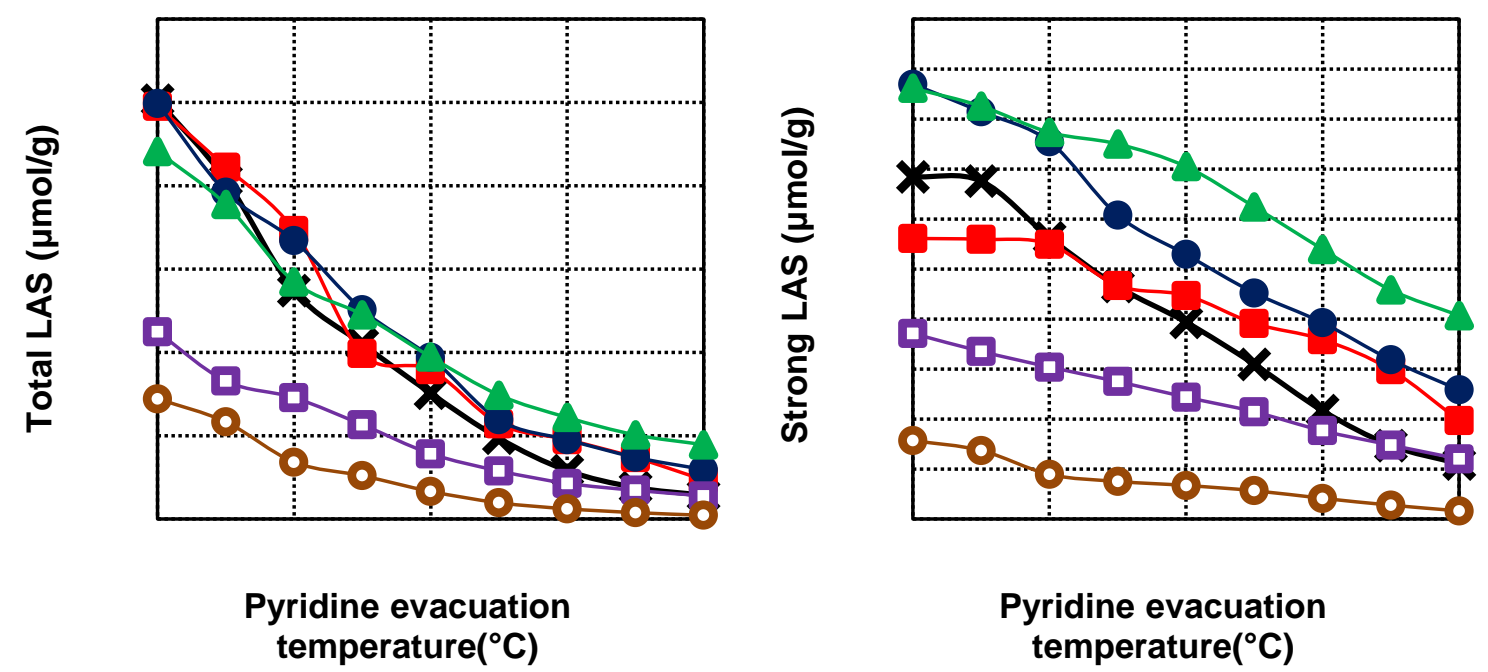

Figure 9. Evolution of the concentration $(\mu \mathrm{mol} / \mathrm{g})$ of the total LAS and strong LAS versus the pyridine evacuation temperature. ( $\boldsymbol{X}) \mathrm{Ag} / \mathrm{Al}_{2} \mathrm{O}_{3} ;(\boldsymbol{\bullet}) \mathrm{Ag} / \mathrm{Zn}_{0.1}-\mathrm{Al}_{2} \mathrm{O}_{3} ;(\bullet) \mathrm{Ag} / \mathrm{Zn} 0.2-\mathrm{Al}_{2} \mathrm{O}_{3} ;$; $(\boldsymbol{\Delta})$ $\mathrm{Ag} / \mathrm{Zn}_{0.33}-\mathrm{Al}_{2} \mathrm{O}_{3} ;$; (口) $\mathrm{Ag} / \mathrm{Zn}_{0.33}-\mathrm{Al}_{2} \mathrm{O}_{3} \mathrm{C} 800$; ( $) \mathrm{Ag} / \mathrm{Zn}_{0.33}-\mathrm{Al}_{2} \mathrm{O}_{3} \mathrm{C} 1000$.

\subsection{NOx selective catalytic reduction with ethanol}

\section{$N O_{x}$ and ethanol conversion}

In this part, the catalytic tests of the $\mathrm{NO}_{\mathrm{x}}$ selective catalytic reduction with ethanol (EtOH-SCR) are presented. Influence of silver addition over the alumina support is discussed, as well as the influence of zinc addition.

Figure 10 shows that silver addition over the alumina support leads to enhance both the $\mathrm{NO}_{\mathrm{x}}$ and ethanol conversions, as reported by Miyadera [27]. The effect of silver addition is more striking concerning $\mathrm{NO}_{\mathrm{x}}$ conversion which is total in the $350-450^{\circ} \mathrm{C}$ temperature range over $\mathrm{Ag} / \mathrm{Al}_{2} \mathrm{O}_{3}$. Effect of zinc addition over these parameters is presented in Table 3 at $300^{\circ} \mathrm{C}$ and $450^{\circ} \mathrm{C}$, which are representatives of the materials activity. At $300^{\circ} \mathrm{C}$, results showed that addition of 10 at. $\%$ of zinc in the alumina structure decreases the ethanol conversion, from $95 \%$ to $76 \%$, as well as the $\mathrm{NO}_{\mathrm{x}}$ conversion from $74 \%$ to $51 \%$. However, addition of 20 and 33 at.\% of zinc leads to better results in $\mathrm{NO}_{\mathrm{x}}$ and ethanol conversions than with the $\mathrm{Ag} / \mathrm{Al}_{2} \mathrm{O}_{3}$ reference 
catalyst. Then, raising the calcination temperature of $\mathrm{Zn}_{0.33}-\mathrm{Al}_{2} \mathrm{O}_{3}$ to $800^{\circ} \mathrm{C}$ leads to even better results in $\mathrm{NO}_{\mathrm{x}}$ conversion, which reaches $100 \%$ at $300^{\circ} \mathrm{C}$. However, raising more the calcination temperature of the support to $1000^{\circ} \mathrm{C}$ leads to inhibit the activity, even compared to $\mathrm{Ag} / \mathrm{Al}_{2} \mathrm{O}_{3}$. For instance, $\mathrm{NO}_{\mathrm{x}}$ conversion reaches only $7 \%$ at $300^{\circ} \mathrm{C}$, contrasting with the total conversion obtained when $\mathrm{Ag} / \mathrm{Zn}_{0.33}-\mathrm{Al}_{2} \mathrm{O}_{3}$ is calcined at $800^{\circ} \mathrm{C}$.

At $450^{\circ} \mathrm{C}$, the ethanol conversion is total (or almost) for all the supports and catalysts. No major differences are observed concerning $\mathrm{NO}_{\mathrm{x}}$ conversion, excepted for $\mathrm{Ag} / \mathrm{Zn}_{0.33}-\mathrm{Al}_{2} \mathrm{O}_{3} \mathrm{C} 1000$ which shows very low activity compared to the other catalysts. Indeed, its $\mathrm{NO}_{\mathrm{x}}$ conversion reaches only $56 \%$.
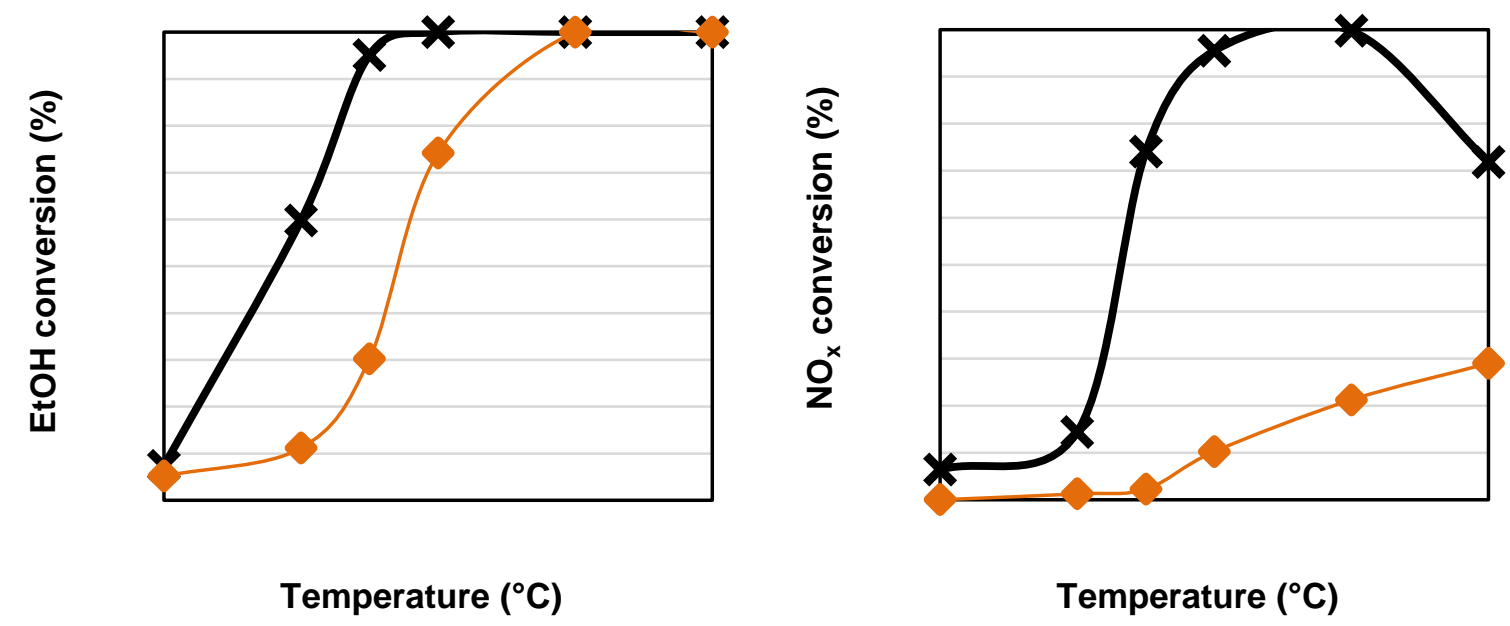

Figure 10. Effect of silver addition over ethanol and $\mathrm{NO}_{\mathrm{x}}$ conversion in EtOH-SCR tests. $\mathrm{Al}_{2} \mathrm{O}_{3} ;(\mathbf{X}) \mathrm{Ag} / \mathrm{Al}_{2} \mathrm{O}_{3}$.

\section{Selectivity in N-products}

In this part, the distribution of the nitrogen containing products observed during the EtOH-SCR test is discussed. First, it is worth mentioning than $\mathrm{N}_{2} \mathrm{O}$ emissions have not been observed over the different supports, or silver supported samples. Firstly, the influence of the silver addition over pure alumina is presented.

Figure 11 shows that $\mathrm{NO}$ is strictly converted into $\mathrm{NO}_{2}$ and $\mathrm{N}_{2}$ over alumina, in the same proportion at $350^{\circ} \mathrm{C}$ and $450^{\circ} \mathrm{C}$. NO oxidation is however favored at $550^{\circ} \mathrm{C}$. 


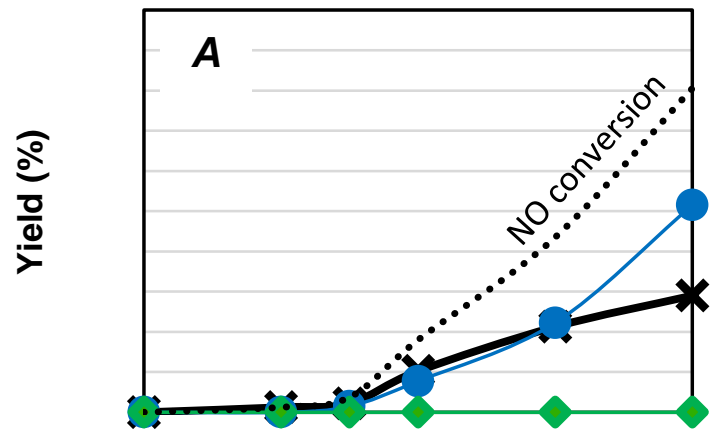

Temperature $\left({ }^{\circ} \mathrm{C}\right)$

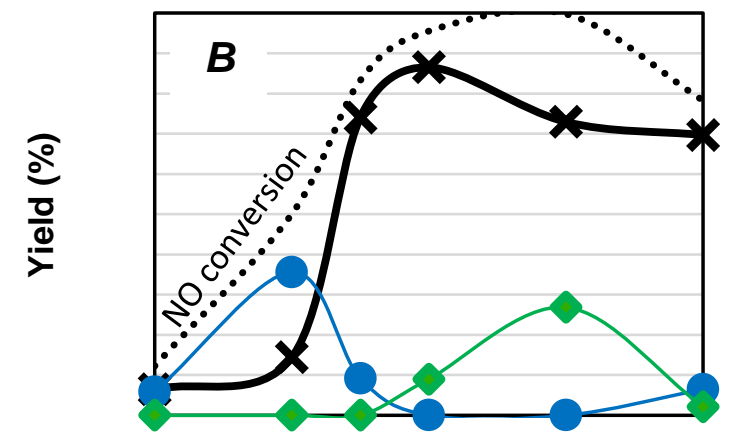

Temperature $\left({ }^{\circ} \mathrm{C}\right)$

Figure 11. Yield of nitrogen products observed during EtOH-SCR tests. $(\mathbf{X}) \mathrm{N}_{2} ;(\bullet) \mathrm{NO}_{2} ;(\bullet)$ $\mathrm{NH}_{3}$. (A): $\mathrm{Al}_{2} \mathrm{O}_{3}$ and (B): $\mathrm{Ag} / \mathrm{Al}_{2} \mathrm{O}_{3}$.

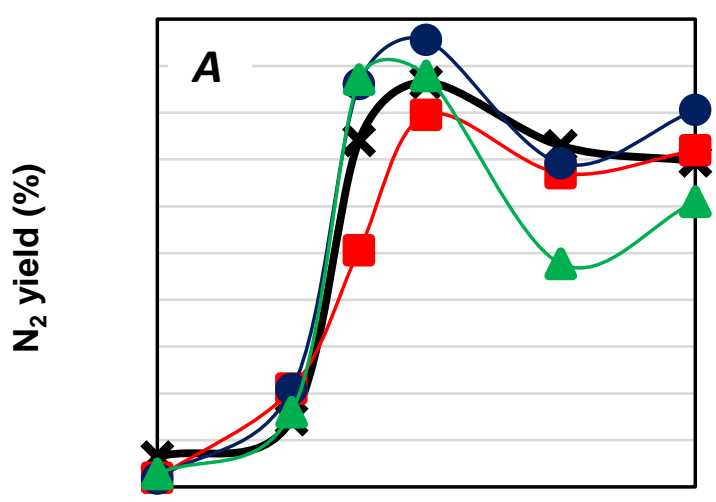

Temperature $\left({ }^{\circ} \mathrm{C}\right)$

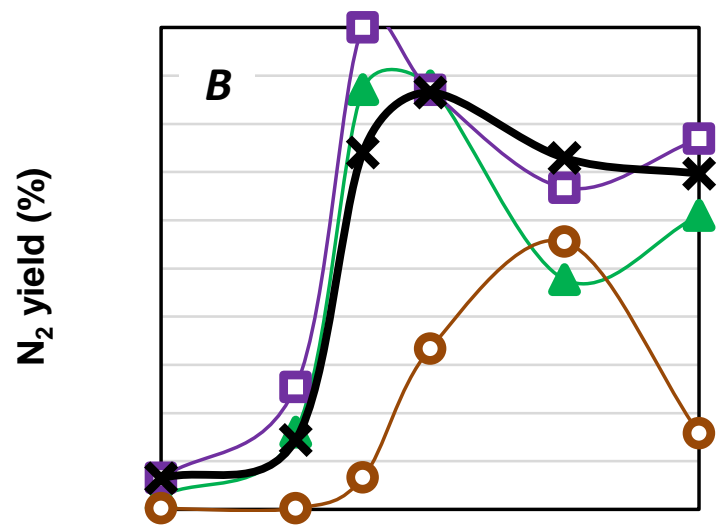

Temperature $\left({ }^{\circ} \mathrm{C}\right)$

Figure 12. Influence of (A) the zinc loading inside $\mathrm{Al}_{2} \mathrm{O}_{3}$ structure and (B) the calcination temperature of $\mathrm{Zn}_{0.33}-\mathrm{Al}_{2} \mathrm{O}_{3}$ over the nitrogen yield in EtOH-SCR tests. ( $\left.\mathbf{X}\right) \mathrm{Ag} / \mathrm{Al}_{2} \mathrm{O}_{3}$; ( $\mathbf{\square}$ ) $\mathrm{Ag} / \mathrm{Zn}_{0.1}-\mathrm{Al}_{2} \mathrm{O}_{3} ;(\bullet) \mathrm{Ag} / \mathrm{Zn}_{0.2}-\mathrm{Al}_{2} \mathrm{O}_{3} ;(\boldsymbol{\Delta}) \mathrm{Ag} / \mathrm{Zn}_{0.33}-\mathrm{Al}_{2} \mathrm{O}_{3} ;$ (口) $\mathrm{Ag} / \mathrm{Zn}_{0.33}-\mathrm{Al}_{2} \mathrm{O}_{3} \mathrm{C} 800 ;$ (०) $\mathrm{Ag} / \mathrm{Zn}_{0.33}-\mathrm{Al}_{2} \mathrm{O}_{3} \mathrm{C} 1000$.

Concerning the $\mathrm{NO}$ conversion over $\mathrm{Ag} / \mathrm{Al}_{2} \mathrm{O}_{3}$ catalyst (Figure 11B), two behaviors are observed depending on the temperature range. Precisely, at low temperature $\left(\mathrm{T} \leq 350^{\circ} \mathrm{C}\right)$, only $\mathrm{NO}_{2}$ and $\mathrm{N}_{2}$ are emitted, whereas at higher temperature, $\mathrm{NO}$ is mainly converted into $\mathrm{N}_{2}$ and $\mathrm{NH}_{3}$, with a maximum ammonia yield of $27 \%$ at $450^{\circ} \mathrm{C}$. Finally, compared to the supports alone, the distribution of the N-products strongly differs. The impact of the support composition over the $\mathrm{NO}_{\mathrm{x}}$ conversion into nitrogen is depicted for each silver supported catalyst on Figure 12. 
Figure 12A shows that addition of 10 at.\% zinc in the alumina structure decreases the nitrogen yield in the $250-550^{\circ} \mathrm{C}$ temperature range, according with the decrease of the $\mathrm{NO}_{\mathrm{x}}$ conversion depicted in the previous section. However, addition of 20 and 33 at.\% zinc increases the $\mathrm{N}_{2}$ yield from $74 \%$ to $86-87 \%$ at $300^{\circ} \mathrm{C}$. At $350^{\circ} \mathrm{C}$, only the addition of 20 at. $\%$ of zinc leads to a better result compared to the $\mathrm{Ag} / \mathrm{Al}_{2} \mathrm{O}_{3}$ reference catalyst, with an increase of the nitrogen yield from 87 to $96 \%$.

Then, Figure 12B shows that raising the calcination temperature of $\mathrm{Zn}_{0.33}-\mathrm{Al}_{2} \mathrm{O}_{3}$ from $600^{\circ} \mathrm{C}$ to $800^{\circ} \mathrm{C}$ leads to an enhancement of the $\mathrm{N}_{2}$ yield over almost the whole temperature range. Compared to $\mathrm{Ag} / \mathrm{Al}_{2} \mathrm{O}_{3}$, the $\mathrm{N}_{2}$ formation is satisfactorily improved at $250^{\circ} \mathrm{C}$ (from $14 \%$ to $25 \%$ ) and at $300^{\circ} \mathrm{C}$ (from $74 \%$ to $100 \%$ ). Raising the calcination temperature of $\mathrm{Zn}_{0.33}-\mathrm{Al}_{2} \mathrm{O}_{3}$ to $1000^{\circ} \mathrm{C}$ leads to a major decrease of the activity. Indeed, nitrogen yield solely reaches $7 \%$ at $300^{\circ} \mathrm{C}$.

Finally, these results clearly show that zinc loading can be a sustainable solution to enhance the activity of $\mathrm{Ag} / \mathrm{Al}_{2} \mathrm{O}_{3}$ in EtOH-SCR at low temperature, which seems easier in a practical way than adding another reductant like $\mathrm{H}_{2}$ [53] in the gas mixture. However, it requires a control of both the $\mathrm{Zn}$ loading inside the alumina structure, and the calcination temperature of the material. Concerning the reaction selectivity, the $\mathrm{NH}_{3}$ and $\mathrm{NO}_{2}$ yields at $250^{\circ} \mathrm{C}$ and $450^{\circ} \mathrm{C}$ are reported in Table 4 for each support and silver supported catalyst. These temperatures are therefore representatives of the catalysts selectivity at low and higher temperature.

The differences in N-products distribution (pointed out previously on Figure 11) between the support and the corresponding silver supported catalyst are here highlighted.

Indeed, at $250^{\circ} \mathrm{C}$, neither $\mathrm{NO}_{2}$ nor $\mathrm{NH}_{3}$ emissions are observed over the supports. However, addition of silver leads to the oxidation of $\mathrm{NO}$ in $\mathrm{NO}_{2}$ at this temperature for every catalyst. Still, no ammonia emission is observed.

At $450^{\circ} \mathrm{C}$, if $\mathrm{NO}_{2}$ emission is observed for every support, addition of silver leads to a disappearance of this emission. On the other hand, emission of ammonia is then observed. Compared with Table 3 and Figure 12, it appears thtn, at $450^{\circ} \mathrm{C}$ and for the whole silver supported catalysts, $\mathrm{NO}_{\mathrm{x}}$ are strictly converted into $\mathrm{NH}_{3}$ and $\mathrm{N}_{2}$. 
Table 4. Effect of zinc addition over the $\mathrm{NH}_{3}$ and $\mathrm{NO}_{2}$ emission at $250^{\circ} \mathrm{C}$ and $450^{\circ} \mathrm{C}$. Comparison between the supports and the corresponding silver supported catalysts.

\begin{tabular}{|c|c|c|c|c|}
\hline \multirow[t]{2}{*}{ Catalysts } & \multicolumn{2}{|c|}{$\mathrm{NH}_{3}$ yield $(\%)$} & \multicolumn{2}{|c|}{$\mathrm{NO}_{2}$ yield $(\%)$} \\
\hline & $250^{\circ} \mathrm{C}$ & $450^{\circ} \mathrm{C}$ & $250^{\circ} \mathrm{C}$ & $450^{\circ} \mathrm{C}$ \\
\hline $\mathrm{Al}_{2} \mathrm{O}_{3}$ & 0 & 0 & 0 & 22 \\
\hline $\mathrm{Ag} / \mathrm{Al}_{2} \mathrm{O}_{3}$ & $\mathbf{0}$ & 27 & 36 & $\mathbf{0}$ \\
\hline $\mathrm{Zn}_{0.1}-\mathrm{Al}_{2} \mathrm{O}_{3}$ & 0 & 0 & 0 & 2 \\
\hline $\mathrm{Ag} / \mathrm{Zn}_{0.1}-\mathrm{Al}_{2} \mathrm{O}_{3}$ & $\mathbf{0}$ & 31 & 12 & $\mathbf{0}$ \\
\hline $\mathrm{Zn}_{0.2}-\mathrm{Al}_{2} \mathrm{O}_{3}$ & 0 & 0 & 0 & 11 \\
\hline $\mathrm{Ag} / \mathrm{Zn}_{0.2}-\mathrm{Al}_{2} \mathrm{O}_{3}$ & $\mathbf{0}$ & 30 & 7 & $\mathbf{0}$ \\
\hline $\mathrm{Zn}_{0.33}-\mathrm{Al}_{2} \mathrm{O}_{3}$ & 0 & 0 & 0 & 10 \\
\hline $\mathrm{Ag} / \mathrm{Zn}_{0.33}-\mathrm{Al}_{2} \mathrm{O}_{3}$ & $\mathbf{0}$ & 52 & 5 & $\mathbf{0}$ \\
\hline $\mathrm{Zn}_{0.33}-\mathrm{Al}_{2} \mathrm{O}_{3} \mathrm{C} 800$ & 0 & 0 & 0 & 7 \\
\hline $\mathrm{Ag} / \mathrm{Zn}_{0.33}-\mathrm{Al}_{2} \mathrm{O}_{3} \mathrm{C800}$ & $\mathbf{0}$ & 33 & 9 & $\mathbf{0}$ \\
\hline $\mathrm{Zn}_{0.33}-\mathrm{Al}_{2} \mathrm{O}_{3} \mathrm{C} 1000$ & 0 & 0 & 0 & 1 \\
\hline $\mathrm{Ag} / \mathrm{Zn}_{0.33}-\mathrm{Al}_{2} \mathrm{O}_{3} \mathrm{C} 1000$ & $\mathbf{0}$ & $\mathbf{0}$ & 2 & $\mathbf{0}$ \\
\hline
\end{tabular}

These results clearly show that addition of silver drastically transformed the $\mathrm{NO}_{\mathrm{x}}$ chemistry observed over the supports alone. The role of the silver sites in the EtOH-SCR process will be developed in the discussion section. The following part presents the transformation of ethanol in carbonated products.

\section{Carbonated products}

In this part, the carbonated products emitted during the EtOH-SCR tests with $\mathrm{Al}_{2} \mathrm{O}_{3}$ and $\mathrm{Ag} / \mathrm{Al}_{2} \mathrm{O}_{3}$ are firstly presented. Then, the influence of the zinc addition over these emissions is developed.

On the alumina support alone, ethanol is converted into $\mathrm{CO}_{2}$, ethylene, acetaldehyde and $\mathrm{CO}$ (Figure 13). However, ethanol is principally converted into ethylene, especially above $300^{\circ} \mathrm{C}$. The $\mathrm{C}_{2} \mathrm{H}_{4}$ yield reaches $73 \%$ at $450^{\circ} \mathrm{C}$. 


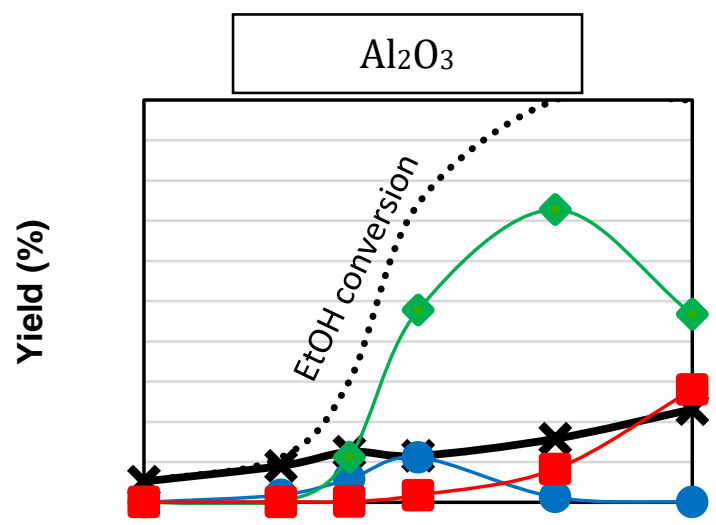

Temperature $\left({ }^{\circ} \mathrm{C}\right)$

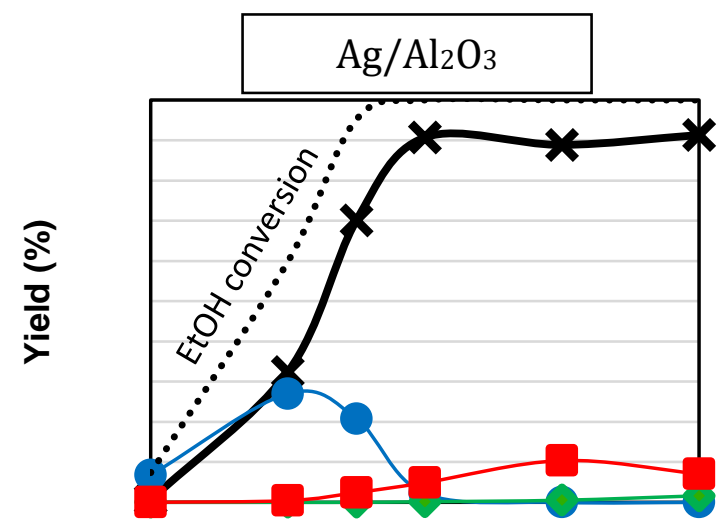

Temperature $\left({ }^{\circ} \mathrm{C}\right)$

Figure 13. Yield of carbonated products observed with $\mathrm{Al}_{2} \mathrm{O}_{3}$ and $\mathrm{Ag} / \mathrm{Al}_{2} \mathrm{O}_{3}$ during EtOH-SCR tests. ( $\mathbf{X}) \mathrm{CO}_{2} ;(\bullet)$ Acetaldehyde; $(\bullet)$ Ethylene; ( $\bullet$ CO.

Addition of silver leads to different results. Indeed, ethanol is then mainly converted into $\mathrm{CO}_{2}$. Emission of acetaldehyde is observed between $150^{\circ} \mathrm{C}$ and $350^{\circ} \mathrm{C}$, with a maximum yield of $28 \%$ at $250^{\circ} \mathrm{C}$, which shows that $\mathrm{Ag}$ favored its formation at low temperature, compared to the support alone. Besides, ethylene emission is suppressed. It suggests that silver interferes with the active sites of the support, responsible for the transformation of ethanol in ethylene. A second assumption is that ethylene is consumed during SCR reaction, as a primary product of $\mathrm{C}_{2} \mathrm{H}_{5} \mathrm{OH}$ reduction. This point will be discussed in the following part. Finally, emission of $\mathrm{CO}$ is also observed, mainly for the higher temperatures.

This study shows that ethanol can be converted into numerous carbonated by-products during the EtOH-SCR process. Alumina and silver species sites are responsible for their formation, depending on the temperature range. Acetaldehyde, ethylene or $\mathrm{CO}$ products can thereafter react with NO to perform the SCR reaction. The reactivity of each of these by-products in NO SCR with $\mathrm{Ag} / \mathrm{Al}_{2} \mathrm{O}_{3}$ has been evaluated, keeping the same carbon concentration, at $2400 \mathrm{ppm}$. Firstly, CO is not able to perform SCR in this condition, and ethylene is active only at $550^{\circ} \mathrm{C}$ (results not shown), which is a too high temperature to consider ethylene as the main reducing agent for $\mathrm{NO}_{\mathrm{x}}$ abatement. In opposite, results obtained with acetaldehyde as reducer (Table 5) show that the $\mathrm{CH}_{3} \mathrm{CHO}-\mathrm{SCR}$ activity is very low at $250^{\circ} \mathrm{C}$, but gradually increases with temperature to be very consistent at $350^{\circ} \mathrm{C}$.

Based on these results, Table 6 reports the emission of acetaldehyde obtained during the EtOHSCR experiments at $250^{\circ} \mathrm{C}$ and $350^{\circ} \mathrm{C}$ for the supports and the silver supported catalysts. 
Table 5. Acetaldehyde conversion and nitrogen yield obtained on $\mathrm{Ag} / \mathrm{Al}_{2} \mathrm{O}_{3}$ catalyst. $1200 \mathrm{ppm}$ $\mathrm{CH}_{3} \mathrm{CHO}, 400 \mathrm{ppm} \mathrm{NO}, 500 \mathrm{ppm} \mathrm{CO}, 167 \mathrm{ppm} \mathrm{H}_{2}, 8 \% \mathrm{O}_{2}, 10 \% \mathrm{H}_{2} \mathrm{O}$ and $10 \% \mathrm{CO}_{2}$ balanced in nitrogen. GHSV $=150000 \mathrm{~h}^{-1}$.

\begin{tabular}{lccc}
\hline Temperature & $250^{\circ} \mathrm{C}$ & $300^{\circ} \mathrm{C}$ & $350^{\circ} \mathrm{C}$ \\
\hline Conv. $\mathrm{CH}_{3} \mathrm{CHO}$ & $4 \%$ & $38 \%$ & $73 \%$ \\
\hline $\mathrm{N}_{2}$ yield & $4 \%$ & $20 \%$ & $84 \%$ \\
\hline
\end{tabular}

Table 6. EtOH-SCR: effect of zinc addition over the acetaldehyde emission at $250^{\circ} \mathrm{C}$ and $350^{\circ} \mathrm{C}$. Comparison between the supports and the corresponding silver supported catalysts.

\begin{tabular}{|c|c|c|}
\hline \multirow[t]{2}{*}{ Catalysts } & \multicolumn{2}{|c|}{$\mathrm{CH}_{3} \mathrm{CHO}$ yield $(\%)$} \\
\hline & $250^{\circ} \mathrm{C}$ & $350^{\circ} \mathrm{C}$ \\
\hline $\mathrm{Al}_{2} \mathrm{O}_{3}$ & 2 & 11 \\
\hline $\mathrm{Ag} / \mathrm{Al}_{2} \mathrm{O}_{3}$ & 27 & 2 \\
\hline $\mathrm{Zn}_{0.1}-\mathrm{Al}_{2} \mathrm{O}_{3}$ & 2 & 14 \\
\hline $\mathrm{Ag} / \mathrm{Zn}_{0.1}-\mathrm{Al}_{2} \mathrm{O}_{3}$ & 15 & 16 \\
\hline $\mathrm{Zn}_{0.2}-\mathrm{Al}_{2} \mathrm{O}_{3}$ & 1 & 5 \\
\hline $\mathrm{Ag} / \mathrm{Zn}_{0.2}-\mathrm{Al}_{2} \mathrm{O}_{3}$ & 30 & 12 \\
\hline $\mathrm{Zn}_{0.33}-\mathrm{Al}_{2} \mathrm{O}_{3}$ & 1 & 5 \\
\hline $\mathrm{Ag} / \mathbf{Z n}_{0.33}-\mathrm{Al}_{2} \mathrm{O}_{3}$ & 29 & 10 \\
\hline $\mathrm{Zn}_{0.33}-\mathrm{Al}_{2} \mathrm{O}_{3} \mathrm{C} 800$ & 1 & 7 \\
\hline $\mathrm{Ag} / \mathrm{Zn}_{0.33}-\mathrm{Al}_{2} \mathrm{O}_{3} \mathrm{C800}$ & 47 & $\mathbf{0}$ \\
\hline $\mathrm{Zn}_{0.33}-\mathrm{Al}_{2} \mathrm{O}_{3} \mathrm{C} 1000$ & 3 & 15 \\
\hline $\mathrm{Ag} / \mathrm{Zn}_{0.33}-\mathrm{Al}_{2} \mathrm{O}_{3} \mathrm{C} 1000$ & 18 & 35 \\
\hline
\end{tabular}


Concerning the $\mathrm{Zn}_{\mathrm{x}}-\mathrm{Al}_{2} \mathrm{O}_{3}$ supports, same results as those presented on $\mathrm{Al}_{2} \mathrm{O}_{3}$ are obtained, showing that addition of zinc does not significantly increase the acetaldehyde emission at $250^{\circ} \mathrm{C}$ or $350^{\circ} \mathrm{C}$, compared with pure alumina. Concerning the silver supported catalysts, Table 6 shows that $\mathrm{CH}_{3} \mathrm{CHO}$ emission grows compare to the silver free supports. At $250^{\circ} \mathrm{C}$, the higher acetaldehyde yield is observed for the $\mathrm{Ag} / \mathrm{Zn}_{0.33}-\mathrm{Al}_{2} \mathrm{O}_{3} \mathrm{C} 800$ catalysts, whereas the lower one is observed with $\mathrm{Ag} / \mathrm{Zn}_{0.1}-\mathrm{Al}_{2} \mathrm{O}_{3}$ and $\mathrm{Ag} / \mathrm{Zn}_{0.33}-\mathrm{Al}_{2} \mathrm{O}_{3} \mathrm{C} 1000$ materials. At $350^{\circ} \mathrm{C}$, addition of zinc leads to an increase of the acetaldehyde emission of silver supported catalysts, except for $\mathrm{Ag} / \mathrm{Zn}_{0.33}-\mathrm{Al}_{2} \mathrm{O}_{3} \mathrm{C} 800$ which presents no $\mathrm{CH}_{3} \mathrm{CHO}$ emission. These differences will be further developed in the discussion section below.

\section{Discussion}

Silver supported catalysts on alumina-based oxides show that incorporation of $\mathrm{Zn}$ into $\mathrm{Al}_{2} \mathrm{O}_{3}$ strongly influences (i) the structural and chemical surface properties of the support and (ii) the silver state. XRD results indicate the formation of zinc aluminate spinel structure, leading to a modification of the $\mathrm{Al}^{3+}{ }_{\mathrm{IV}} / \mathrm{Al}^{3+}{ }_{\mathrm{VI}}$ coordinative unsaturated sites ratio. From $\mathrm{UV}-\mathrm{V}$ is results, it appears that silver is mainly present as highly dispersed silver ions $\left(\mathrm{Ag}^{+}\right)$on $\mathrm{Ag} / \mathrm{Al}_{2} \mathrm{O}_{3}$ samples. $\mathrm{Zn}$ addition enhances the amount of oxidized $\mathrm{Ag}_{\mathrm{n}}{ }^{\delta+}$ cluster and metallic $\mathrm{Ag}^{0}$ species but drop down the percentage of $\mathrm{Ag}^{+}$. Besides, TEM and TPR experiments indicate that the higher the $\mathrm{Zn}$ loading, the higher the silver metallic particle size. Catalytic results show that the reduction of $\mathrm{NO}_{\mathrm{x}}$ by ethanol starts at $250^{\circ} \mathrm{C}$, and gradually increases to $100 \%$ at $\mathrm{T} \geq 350^{\circ} \mathrm{C}$ (Figure 10 ). Based on these results, two range of temperature were studied separately $\left(\mathrm{T} \leq 350^{\circ} \mathrm{C}\right.$ and $\mathrm{T} \geq$ $350^{\circ} \mathrm{C}$ ) in the following section.

\subsection{Nitrogen formation at low temperature $\left(T \leq 350^{\circ} \mathrm{C}\right)$}

At low temperature (i.e. $\mathrm{T} \leq 350^{\circ} \mathrm{C}$ ) EtOH-SCR test (Figure 13 and Table 6) show that $\mathrm{CH}_{3} \mathrm{CHO}$ is one of the main carbonated compounds detected at $250^{\circ} \mathrm{C}$, when the $\mathrm{NO}_{\mathrm{x}}$ conversion is low. Indeed, acetaldehyde yield reaches $47 \%$ at $250{ }^{\circ} \mathrm{C}$ for the $\mathrm{Ag} / \mathrm{Zn}_{0.33}-\mathrm{Al}_{2} \mathrm{O}_{3} \mathrm{C} 800$ catalyst, whereas $25 \%$ of $\mathrm{NO}_{\mathrm{x}}$ are converted. As reported in the literature [37, 81], the acetaldehyde reactivity is the first step in EtOH-SCR mechanism. Thus, the $\mathrm{NO}_{x}$ reduction with $\mathrm{CH}_{3} \mathrm{CHO}$ $\left(\mathrm{CH}_{3} \mathrm{CHO}-\mathrm{SCR}\right)$ was studied over the whole samples. Results reported in Table 5 show that acetaldehyde conversion increases with temperature, from $4 \%$ to $73 \%$, at $250^{\circ} \mathrm{C}$ and $350^{\circ} \mathrm{C}$ 
respectively. In parallel, $\mathrm{N}_{2}$ yield growths from $4 \%$ to $84 \%$. From these results, it appears that acetaldehyde is not an effective $\mathrm{NO}_{\mathrm{x}}$ reducer at $250^{\circ} \mathrm{C}$, contrary to $350^{\circ} \mathrm{C}$. As a matter of comparison, in usual EtOH-SCR test, $\mathrm{N}_{2}$ yield rates between $18 \%$ and $27 \%$ at $250^{\circ} \mathrm{C}$ (Figure 12) and $\mathrm{CH}_{3} \mathrm{CHO}$ yield can reach $47 \%$. Thus, $\mathrm{CH}_{3} \mathrm{CHO}$ emitted at $250^{\circ} \mathrm{C}$ from EtOH-SCR can be used to assess the dehydrogenation activity of the catalysts. In addition, $\mathrm{CH}_{3} \mathrm{CHO}$ detected at higher temperature $\left(\right.$ i.e. $\left.350^{\circ} \mathrm{C}\right)$, when $\mathrm{NO}_{\mathrm{x}}$ reduction is effective, illustrates the consumption of $\mathrm{CH}_{3} \mathrm{CHO}$ for the $\mathrm{NO}_{\mathrm{x}}$ reduction. So, it is proposed that the gap between the acetaldehyde yield measured at $250{ }^{\circ} \mathrm{C}$ and $350{ }^{\circ} \mathrm{C}$ (Table 6) during the EtOH-SCR test (denoted as $\mathrm{CH}_{3} \mathrm{CHO}$ activity) is an experimental parameter representative of the catalyst activity in $\mathrm{CH}_{3} \mathrm{CHO}-\mathrm{SCR}$. Based on this assumption, Figure 14A reports the $\mathrm{N}_{2}$ yield versus the $\mathrm{CH}_{3} \mathrm{CHO}$ activity parameter. The higher the gap between acetaldehyde yield at $250^{\circ} \mathrm{C}$ and $350^{\circ} \mathrm{C}$, the higher the $\mathrm{CH}_{3} \mathrm{CHO}$ activity. Whatever the catalysts used in this work, the nitrogen yield at $300^{\circ} \mathrm{C}$ increases alongside the $\mathrm{CH}_{3} \mathrm{CHO}$ activity, showing that the higher the $\mathrm{CH}_{3} \mathrm{CHO}$ activity parameter, the higher the $\mathrm{N}_{2}$ production. This result confirms that key parameters in EtOH-SCR are i) the activation of the ethanol dehydrogenation reaction, and ii) the acetaldehyde reactivity in $\mathrm{DeNO}_{\mathrm{x}}$ mechanism.

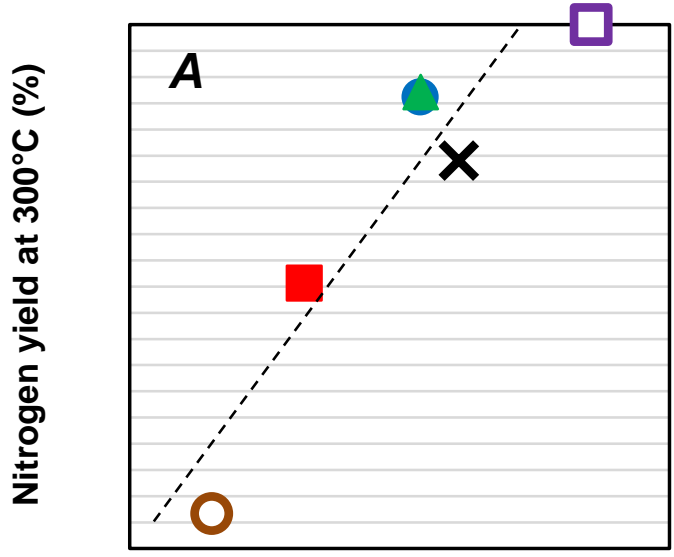

$\mathrm{CH}_{3} \mathrm{CHO}$ activity (\%)

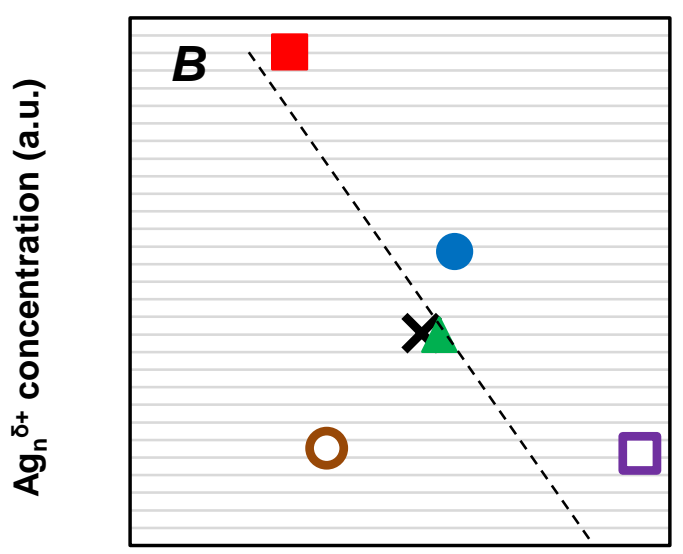

$\mathrm{CH}_{3} \mathrm{CHO}$ yield at $250^{\circ} \mathrm{C}(\%)$

Figure 14: Relation between (A) the $\mathrm{CH}_{3} \mathrm{CHO}$ activity during the EtOH-SCR test and the nitrogen yield obtained at $300^{\circ} \mathrm{C}(\mathrm{B})$ the $\mathrm{CH}_{3} \mathrm{CHO}$ formation at $250^{\circ} \mathrm{C}$ and the relative concentration of $\mathrm{Ag}_{\mathrm{n}}{ }^{\delta+}$ species. (X) $\mathrm{Ag} / \mathrm{Al}_{2} \mathrm{O}_{3} ;(\bullet) \mathrm{Ag} / \mathrm{Zn}_{0.1}-\mathrm{Al}_{2} \mathrm{O}_{3} ;(\bullet) \mathrm{Ag} / \mathrm{Zn}_{0.2}-\mathrm{Al}_{2} \mathrm{O}_{3} ;(\boldsymbol{\Delta}) \mathrm{Ag} / \mathrm{Zn}_{0.33}-\mathrm{Al}_{2} \mathrm{O}_{3} ;$ (口) $\mathrm{Ag} / \mathrm{Zn}_{0.33}-\mathrm{Al}_{2} \mathrm{O}_{3}$ $\mathrm{C} 800 ;(\mathrm{O}) \mathrm{Ag} / \mathrm{Zn}_{0.33}-\mathrm{Al}_{2} \mathrm{O}_{3} \mathrm{C} 1000$. 
Finally, $\mathrm{Ag} / \mathrm{Zn}_{0.33}-\mathrm{Al}_{2} \mathrm{O}_{3} \mathrm{C} 800$ catalyst is the sample who presents the higher $\mathrm{CH}_{3} \mathrm{CHO}$ activity $(+50 \%)$, leading to the highest $\mathrm{NO}_{\mathrm{x}}$ conversion into $\mathrm{N}_{2}$. Table 6 shows that the main difference between this catalyst and $\mathrm{Ag} / \mathrm{Al}_{2} \mathrm{O}_{3}$ is the $\mathrm{CH}_{3} \mathrm{CHO}$ formation at $250^{\circ} \mathrm{C}$, which is 20 yield points higher for $\mathrm{Ag} / \mathrm{Zn}_{0.33}-\mathrm{Al}_{2} \mathrm{O}_{3} \mathrm{C} 800$. No significant differences are observed in $\mathrm{CH}_{3} \mathrm{CHO}$ consumption at $350^{\circ} \mathrm{C}$. Yet, it is well known that ethanol dehydrogenation occurs either on the support basic sites or on the metal function of the catalyst [82]. However, since no differences in basic sites have been observed over the different samples, it is likely that the silver phase is responsible for the variation in the acetaldehyde formation at $250^{\circ} \mathrm{C}$.

In this work, silver characterizations were performed using TEM, UV-Visible spectroscopy and $\mathrm{H}_{2}$-TPR. It appears that $\mathrm{Zn}$ incorporation inside the alumina structure, then raising the calcination temperature of the $\mathrm{Zn}_{0.33}-\mathrm{Al}_{2} \mathrm{O}_{3}$ support, both increase the average size of the silver particles. As presented in Table 2, the metallic silver content (MSC) does not vary (at around $67 \%$ ) when zinc is loaded inside the alumina structure, but rises when the calcination temperature of $\mathrm{Zn}_{0.33}-\mathrm{Al}_{2} \mathrm{O}_{3}$ is increased from $600^{\circ} \mathrm{C}$ to $800^{\circ} \mathrm{C}(\mathrm{MSC}=77 \%)$ and to $1000^{\circ} \mathrm{C}$ $(\mathrm{MSC}=80 \%)$. These particles are thereby reducible at lower temperature (Table 2). Thus, the increase of the metallic silver content, together with the lowering of the reduction temperature of the silver particles, can explain the increase of $\mathrm{CH}_{3} \mathrm{CHO}$ formation at $250^{\circ} \mathrm{C}$ with $\mathrm{Ag} / \mathrm{Zn}_{0.33^{-}}$ $\mathrm{Al}_{2} \mathrm{O}_{3} \mathrm{C} 800$ compared to $\mathrm{Ag} / \mathrm{Al}_{2} \mathrm{O}_{3}$. Besides, UV-Vis spectra deconvolution indicates that the silver state distribution is strongly affected by $\mathrm{Zn}$ incorporation and the temperature calcination. Figure 14B show that, except for the $\mathrm{Ag} / \mathrm{Zn}_{0.33}-\mathrm{Al}_{2} \mathrm{O}_{3} \mathrm{C} 1000$ sample, the $\mathrm{CH}_{3} \mathrm{CHO}$ formation at $250^{\circ} \mathrm{C}$ is not catalyzed by the oxidized $\mathrm{Ag}_{\mathrm{n}}{ }^{8+}$ cluster amount. These results are consistent with TEM and $\mathrm{H}_{2}$-TPR experiments, showing that ethanol dehydrogenation is mainly catalyzed by metallic sites. Concerning $\mathrm{Ag} / \mathrm{Zn}_{0.33}-\mathrm{Al}_{2} \mathrm{O}_{3} \mathrm{C} 1000$, it is likely that the low surface area of the support $\left(\mathrm{S}_{\mathrm{BET}}=65 \mathrm{~m}^{2} / \mathrm{g}\right)$ is responsible for its low EtOH-SCR activity. Indeed, the surface area of $\mathrm{Ag} / \mathrm{Zn}_{0.33}-\mathrm{Al}_{2} \mathrm{O}_{3} \mathrm{C} 800$ is twice higher $\left(\mathrm{S}_{\mathrm{BET}}=117 \mathrm{~m}^{2} / \mathrm{g}\right)$. These results show that the support sites are implicated in the EtOH dehydrogenation as well.

Finally, the superior catalytic performance of the $\mathrm{Ag} / \mathrm{Zn}_{0.33}-\mathrm{Al}_{2} \mathrm{O}_{3} \mathrm{C} 800$ catalyst is attributed to its unique surface structure and the strong interactions between the support and the silver active phase. Ethanol dehydrogenation is mainly dependent on the metal-support interaction, as supported by other studies $[83,84]$. 


\subsection{Nitrogen and ammonia formation at high temperature $\left(\mathrm{T} \geq 350^{\circ} \mathrm{C}\right)$}

At high temperature (i.e. $\mathrm{T} \geq 350^{\circ} \mathrm{C}$ ) results presented Figure $11 \mathrm{~B}$ and Table 4 show that the obtained total $\mathrm{NO}_{\mathrm{x}}$ conversion is concomitant with significant emission of ammonia, whatever the catalysts. For instance, the $\mathrm{NH}_{3}$ selectivity/yield reaches $50 \%$ at $450^{\circ} \mathrm{C}$ with $\mathrm{Ag} / \mathrm{Zn}_{0.33^{-}}$ $\mathrm{Al}_{2} \mathrm{O}_{3}$. To our knowledge, such emission is not highlighted in the literature. Proposed mechanisms suggest the formation of surface acetate ions or enolic surface species [38] that furthermore react with $\mathrm{NO}_{2}$ to produce nitromethane, leading to the production of isocyanate intermediate species (reaction (1), $c f$. Introduction). The formation of -NCO species has been observed in numerous papers $[85,86]$ over $\mathrm{Ag} / \mathrm{Al}_{2} \mathrm{O}_{3}$ catalysts when high $\mathrm{NO}_{\mathrm{x}}$ reduction efficiency is achieved. The chemistry of HNCO formation is well established [37, 41] and involves hydrolysis of $\mathrm{HNCO}$ to form $\mathrm{NH}_{3}$, via reaction (2). Ammonia can thereafter react with $\mathrm{NO}_{2}$ to form ammonium nitrite (reaction (3)). Ammonium nitrite is thermally unstable above $100^{\circ} \mathrm{C}$ and decomposes to form $\mathrm{H}_{2} \mathrm{O}$ and $\mathrm{N}_{2}$. Isocyanate ions can also react with $\mathrm{NO}_{2}$ [37] at low temperature $\left(e . g\right.$. below $\left.200^{\circ} \mathrm{C}\right)$. This reaction is however slower than that of $\mathrm{NCO}^{-}$with water, which leads to ammonia formation.

Besides, it was recently established that aluminum sites, with two possible coordination states (tetrahedral $\mathrm{Al}_{(\mathrm{IV})}$ and octahedral $\mathrm{Al}_{(\mathrm{VI})}$ ), greatly influence the catalytic performances and selectivity in the $\mathrm{NO}_{x}$ removal process over $\mathrm{Ag} / \mathrm{Al}_{2} \mathrm{O}_{3}[36,51]$. Thus, Figure 15 reports the amount of $\mathrm{NH}_{3}$ yield detected at $450^{\circ} \mathrm{C}$ versus the pyridine coordinated at $450^{\circ} \mathrm{C}$. However, note that coordinative unsaturated sites of catalysts have been characterized by in-situ IR experiments, outgassing at $450^{\circ} \mathrm{C}$. On the contrary, water added in the feed stream during the catalytic test could lead to the formation of new $\mathrm{OH}$ groups by dissociation on Lewis acid-base pairs. However, in this temperature range (i.e $\mathrm{T} \geq 350^{\circ} \mathrm{C}$ ), it is assuming that the influence of water adsorption is weak. Firstly, the relationship between ammonia yield and the total amount of LAS is examined. Figure 15A shows that $\mathrm{NH}_{3}$ emission growth with the total LAS quantity. More specifically, strong $\left(\mathrm{Al}^{3+}{ }_{\mathrm{IV}}\right)$ and weak $\left(\mathrm{Al}^{3+}{ }_{\mathrm{VI}}\right)$ Lewis acid sites were identified as the origin of the - $\mathrm{NCO}$ spill over [29], through a transfer of the isocyanate from $\mathrm{Al}_{(\mathrm{VI})}$ to $\mathrm{Al}_{(\mathrm{IV})}$. Thibault-Starzyk et al. [51] showed that -NCO species are formed at the interface between $\mathrm{Ag}_{\mathrm{n}}{ }^{\delta+}$ silver cluster and $\mathrm{Al}^{3+}$ (VI) weak Lewis acidic sites of the alumina support. Authors showed that a $\mathrm{Ag}_{\mathrm{n}}{ }^{\delta+}-\mathrm{CN}-\mathrm{Al} \mathrm{VI}_{\mathrm{I}}$ bridge is formed first. Then, $-\mathrm{CN}$ - spills over the $\mathrm{Al} \mathrm{VI}_{\mathrm{I}}$ center, and is further oxidized to form the isocyanate ( $\left.\mathrm{Al}_{\mathrm{VI}}\right)$-NCO specie. Yet, since ammonia formation comes from the hydrolysis of $-\mathrm{NCO}$, it must as well be linked to the $\mathrm{Al}^{3+}{ }_{(\mathrm{VI})}$ centers of the alumina support. 


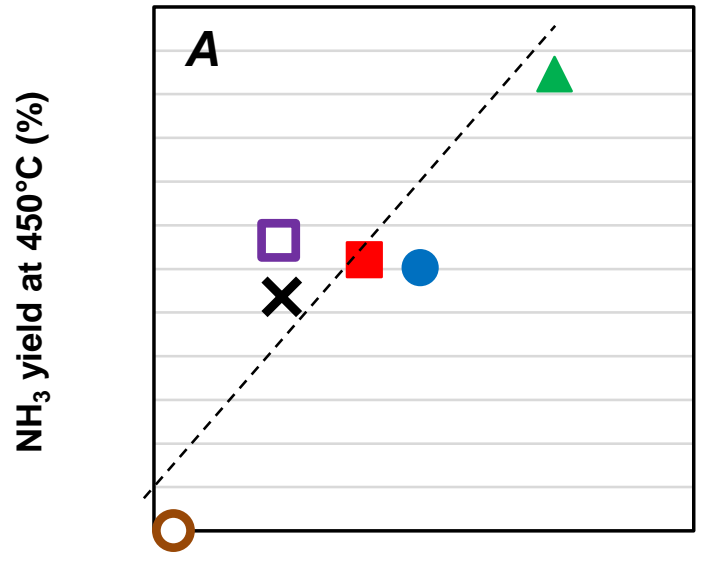

Total LAS concentration $(\mu \mathrm{mol} / \mathrm{g})$ fom pyridine evacuated at $450^{\circ} \mathrm{C}$

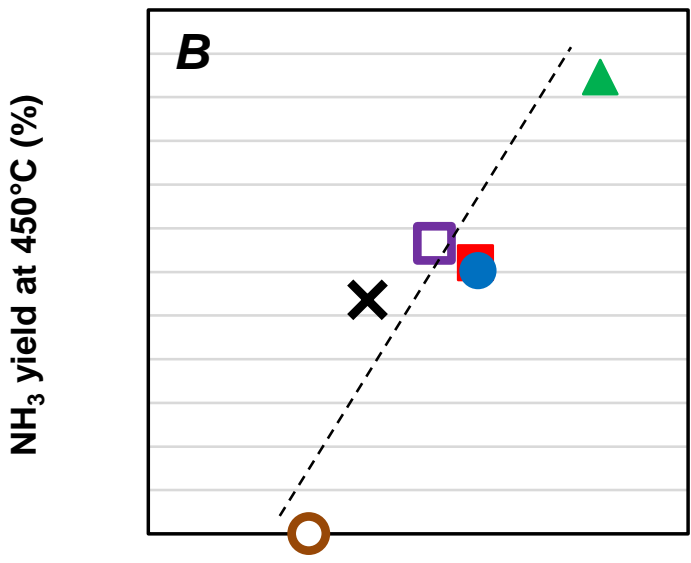

Medium LAS density $\left(\mu \mathrm{mol} / \mathrm{m}^{2}\right)$ fom pyridine evacuated at $450^{\circ} \mathrm{C}$

Figure 15. Relationship between the ammonia yield at $450^{\circ} \mathrm{C}$ versus pyridine coordinated at $450^{\circ} \mathrm{C}$ in function of (A) the total amount of LAS ( $\mu \mathrm{mol} / \mathrm{g})$; (B): the density of medium LAS $\left(\mu \mathrm{mol} / \mathrm{m}^{2}\right)$ obtained by integration of the $v_{8 \mathrm{a}}$ at $1617 \mathrm{~cm}^{-1}$.. (X) $\mathrm{Ag} / \mathrm{Al}_{2} \mathrm{O}_{3} ;(\boldsymbol{\bullet}) \mathrm{Ag} / \mathrm{Zn}_{0.1}-\mathrm{Al}_{2} \mathrm{O}_{3} ;(\bullet) \mathrm{Ag} / \mathrm{Zn}_{0.2}-\mathrm{Al}_{2} \mathrm{O}_{3} ;(\mathbf{\Delta})$ $\mathrm{Ag} / \mathrm{Zn}_{0.33}-\mathrm{Al}_{2} \mathrm{O}_{3} ;(\square) \mathrm{Ag} / \mathrm{Zn}_{0.33}-\mathrm{Al}_{2} \mathrm{O}_{3} \mathrm{C} 800 ;$ ( $) \mathrm{Ag} / \mathrm{Zn}_{0.33}-\mathrm{Al}_{2} \mathrm{O}_{3} \mathrm{C} 1000$.

In this context, the ammonia yield was thus regarded as a function of the medium $\mathrm{Al}^{3+}{ }_{(\mathrm{VI})}$ Lewis acid site density (Figure 15B), determined by integration of $v_{8 a}\left(1617 \mathrm{~cm}^{-1}\right)$ of pyridine evacuated at $450^{\circ} \mathrm{C}$ (Table 1).

The increase in medium LAS density, involving the entire weak $\mathrm{Al}^{3+}{ }_{(\mathrm{VI})}$ centers, results in a linearly growth of the ammonia yield. Yet ammonia formation is only observed with silver supported materials (contrary to the supports alone, $c f$. Table 4). So, this relation suggests a strong interaction between the silver active sites and the acidic ones located on alumina surface or zinc aluminate layer. This conclusion is in accordance with the $\mathrm{Ag}_{\mathrm{n}}{ }^{\delta+}-\mathrm{CN}-\mathrm{Al} \mathrm{l}_{\mathrm{VI}}$ bridge described by Thibault-Starzyk et al. [51], which shows that both sites are needed to form $\mathrm{NCO}$, and then ammonia.

Then, equation 3 denoted a stoechiometric reaction between $\mathrm{NH}_{3}$ and $\mathrm{NO}_{2}$, leading to the nitrogen formation. To be selective into $\mathrm{N}_{2}$, introduced $\mathrm{NO}$ must be equally transformed into $\mathrm{NO}_{2}$ and $\mathrm{NH}_{3}$. Yet, isocyanate hydrolysis reaction pathway is enhanced by a high $\mathrm{Al}^{3+}(\mathrm{VI})$ unsaturated sites density, as illustrated in Scheme 1. It explains why when the $\mathrm{Al}^{3+}$ (VI) density is too high, $\mathrm{NH}_{3}$ slip can occur. Moreover, the higher the $\mathrm{Al}^{3+}$ (VI) density, the higher the ammonia emission. 

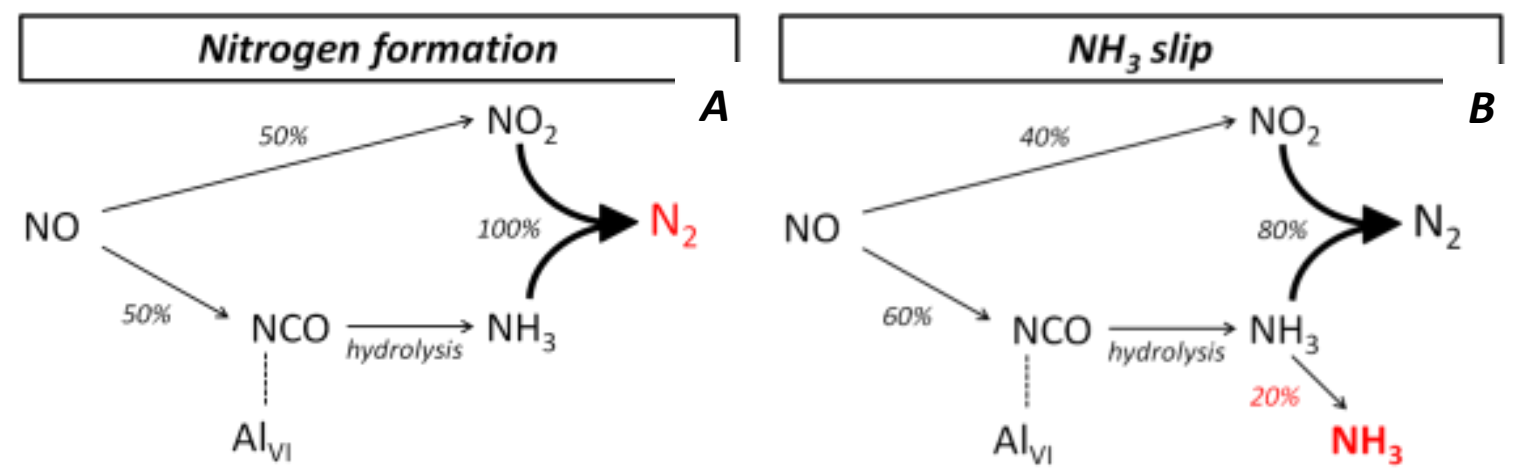

Scheme 1. Involvement of $\mathrm{Al}^{3+}$ (VI) centers in (A) nitrogen formation by $\mathrm{NO}_{2}$ reduction with $\mathrm{NH}_{3}$; (B) $\mathrm{NH}_{3}$ slip.

$(\%)=$ percentage of converted product.

\section{Conclusion}

Surface and metallic properties of $\mathrm{Ag} / \mathrm{Zn}_{\mathrm{x}}-\mathrm{Al}_{2} \mathrm{O}_{3}$ catalysts have been characterized, in regard with the selective catalytic reduction of NOx with ethanol. A special attention was paid to the effect of the calcination temperature (from $600^{\circ} \mathrm{C}$ up to $1000^{\circ} \mathrm{C}$ ), as well as the $\mathrm{Zn}$ content.

$\mathrm{Zn}$ incorporation into the alumina network leads to the formation of the $\mathrm{ZnAl}_{2} \mathrm{O}_{4}$ spinel structure. In parallel, variations in acidity of the resulting supports have been observed, contrarily to their basicity. Precisely, zinc addition modifies the support Lewis acidic sites (LAS) amount and density. Metallic phase characterizations show that silver state on these materials is complex. It appears that all samples present oxidized and metallic particles, in various ratios. The metallic silver / oxidized silver species ratio is not affected by the percentage of zinc loaded into the alumina (from $0.10 \%$ to $0.33 \%$ ), but increases with the calcination temperature of the support (from $600^{\circ} \mathrm{C}$ to $1000^{\circ} \mathrm{C}$ for the $\mathrm{Zn}_{0.33}-\mathrm{Al}_{2} \mathrm{O}_{3}$ support). However, zinc addition leads to an increase of the silver particle mean size. Besides, different silver oxidized species have been identified whatever the support: $\mathrm{Ag}^{+}$ions and $\mathrm{Ag}_{\mathrm{n}}{ }^{\delta+}$ clusters. These species are assumed, in the literature, to be involved in the SCR activity. $\mathrm{Ag}^{+}$ions are showed to decrease in parallel with an increase of the $\mathrm{Ag}_{\mathrm{n}}{ }^{\delta+}$ clusters, when zinc is loaded into the alumina. The opposite phenomenon is observed when the calcination temperature of $\mathrm{Zn}_{0.33}-\mathrm{Al}_{2} \mathrm{O}_{3}$ support is raised from $600^{\circ} \mathrm{C}$ to $1000^{\circ} \mathrm{C}$.

EtOH-SCR tests demonstrate the benefit of zinc addition for $\mathrm{NO}_{\mathrm{x}}$ conversion in nitrogen. The higher efficiency was obtained with the $\mathrm{Ag} / \mathrm{Zn}_{0.33}-\mathrm{Al}_{2} \mathrm{O}_{3} \mathrm{C} 800$ formulation, which yields $100 \%$ $\mathrm{N}_{2}$ at $300^{\circ} \mathrm{C}$, compared to $73 \%$ for the $\mathrm{Ag} / \mathrm{Al}_{2} \mathrm{O}_{3}$ reference sample. This higher performance is 
explained by the activation of the ethanol conversion in acetaldehyde. It is proposed that metallic silver, together with support sites, are responsible for the dehydrogenation of ethanol into acetaldehyde. Activation of acetaldehyde formation at $250^{\circ} \mathrm{C}$ on $\mathrm{Ag} / \mathrm{Zn}_{\mathrm{x}}-\mathrm{Al}_{2} \mathrm{O}_{3} \mathrm{C} 800$ compared to $\mathrm{Ag} / \mathrm{Al}_{2} \mathrm{O}_{3}$ must be partly correlated to its increase in the silver particles mean size. Indeed, it leads to a lowering of the maximum reduction temperature of the silver particles, from $319^{\circ} \mathrm{C}$ to $235^{\circ} \mathrm{C}$. It was also demonstrated that the $\mathrm{CH}_{3} \mathrm{CHO}$ activity directly impacts the $\mathrm{N}_{2}$ yield at $300^{\circ} \mathrm{C}$. The higher the $\mathrm{CH}_{3} \mathrm{CHO}$ activity parameter, the higher the nitrogen formation at $300^{\circ} \mathrm{C}$.

Finally, it has been showed that the Lewis acidic sites (LAS) interfere in the N-products selectivity, more especially in ammonia emission. Particularly, weak LAS are identified as active sites involved in the formation of isocyanate species, which can thereafter react with $\mathrm{NO}_{2}$ to form nitrogen. Selective conversion of $\mathrm{NO}_{\mathrm{x}}$ into nitrogen requires an equal transformation of $\mathrm{NO}$ into $\mathrm{NO}_{2}$ or $-\mathrm{NCO}$ species. When the LAS density is too high, the balance tends toward $\mathrm{NCO}$ formation, which can react with $\mathrm{H}_{2} \mathrm{O}$ to yield ammonia in absence of $\mathrm{NO}_{\mathrm{x}}$. It is proposed that the active site for $-\mathrm{NCO}$ formation is a silver species close to a Lewis acidic site of the support.

\section{References:}

[1] W.S. Epling, L.E. Campbell, A. Yezerets, N.W. Currier, J.E. Parks, Catalysis Reviews-Science and Engineering 46 (2004) 163-245.

[2] H.L. Fang, H.F.M. DaCosta, Applied Catalysis B-Environmental 46 (2003) 17-34.

[3] M. Eichelbaum, R.J. Farrauto, M.J. Castaldi, Applied Catalysis B-Environmental 97 (2010) 90-97.

[4] F. Birkhold, U. Meingast, P. Wassermann, O. Deutschmann, Applied Catalysis B-Environmental 70 (2007) 119-127.

[5] F.Z. Everton, Chemical Engineering Science 64 (2009) 1075 1084 .

[6] M. Koebel, M. Elsener, M. Kleemann, Catalysis Today 59 (2000) 335-345.

[7] M. Koebel, M. Elsener, Journal of Chromatography A 689 (1995) 164-169.

[8] O. Kroecher, M. Elsener, Chemical Engineering Journal 152 (2009) 167-176.

[9] A. Lundstrom, B. Andersson, L. Olsson, Chemical Engineering Journal 150 (2009) 544-550.

[10] G. Piazzesi, O. Krocher, M. Elsener, A. Wokaun, Applied Catalysis B-Environmental 65 (2006) 55-61. 
[11] J.A. Sullivan, J.A. Doherty, Applied Catalysis B-Environmental 55 (2005) 185-194.

[12] A. Grossale, I. Nova, E. Tronconi, D. Chatterjee, M. Weibel, Topics in Catalysis 52 (2009) 1837-1841.

[13] J.H.Park, H.J.Park, J.H. Baik, I.S. Nam, C.H. Shin, J.H. Lee, B.K. Cho, S.H. Oh, Journal of Catalysis 240 (2006) 47-57.

[14] J.A. Sullivan, O. Keane, Applied Catalysis B-Environmental 61 (2005) $244-252$.

[15] M. Konsolakis, I.V. Yentekakis, Journal of Catalysis 198 (2001) $142-150$.

[16] J. Shibata, K. Shimizu, A. Satsuma, T. Hattori, Applied Catalysis B-Environmental 37 (2002) 197-204.

[17] E.F. Iliopoulou, A.P. Evdou, A.A. Lemonidou, I.A. Vasalos, Applied Catalysis a-General 274 (2004) 179-189.

[18] K. Arve, F. Klingstedt, K. Eranen, J. Warna, L.E. Lindfors, D.Y. Murzin, Chemical Engineering Journal 107 (2005) 215-220.

[19] I. Sobczak, M. Ziolek, M. Nowacka, Microporous and Mesoporous Materials 78 (2005) 103-116.

[20] S.C. Shen, S. Kawi, Applied Catalysis B-Environmental 45 (2003) 63-76.

[21] L.F. Cordoba, W.M.H. Sachtler, C.M. de Correa, Applied Catalysis B-Environmental 56 (2005) 269-277.

[22] I.V. Yentekakis, V. Tellou, G. Botzolaki, I.A. Rapakousios, Applied Catalysis B-Environmental 56 (2005) 229-239.

[23] T. Maunula, J. Ahola, H. Hamada, Applied Catalysis BEnvironmental 26 (2000) 173-192.

[24] V. Houel, P. Millington, R. Rajaram, A. Tsolakis, Applied Catalysis B-Environmental 77 (2007) 29-34.

[25] B. Sawatmongkhon, A. Tsolakis, S. Sitshebo, J. RodriguezFernandez, M. Ahmadinejad, J. Collier, R.R. Rajaram, Applied Catalysis B-Environmental 97 (2010) 373-380.

[26] V. Houel, P. Millington, R. Rajaram, A. Tsolakis, Applied Catalysis B-Environmental 73 (2007) 203-207.

[27] T. Miyadera, Applied Catalysis B, Environmental 2 (1993) 199 205.

[28] M. Luo, B. Zhu, L. Zhou, X. Yuan, 24 (1996) 201.

[29] J.A. Rodriguez, M. Kuhn, J. Hrbek, Journal of Physical Chemistry 100 (1996) 18240-18248.

[30] N. Aoyama, K. Yoshida, A. Abe, T. Miyadera, Catalysis Letters 43 (1997) 249-253.

[31] N. Bion, J. Saussey, C. Hedouin, T. Seguelong, M. Daturi, Physical Chemistry Chemical Physics 3 (2001) 4811-4816.

[32] N. Bogdanchikova, F.C. Meunier, M. Avalos-Borja, J.P. Breen, A. Pestryakov, Applied Catalysis B: Environmental 36 (2002) 287-297.

[33] A. Satsuma, J. Shibata, A. Wada, Y. Shinozaki, T. Hattori, 145 (2002) $235-238$. 
[34] E.M. Cordi, J.L. Falconer, Applied Catalysis A: General 151 (1997) 179-191.

[35] S. Kameoka, Y. Ukisu, T. Miyadera, Physical Chemistry Chemical Physics 2 (2000) 367-372.

[36] Z.M. Wang, M. Yamaguchi, I. Goto, M. Kumagai, Physical Chemistry Chemical Physics 2 (2000) 3007-3015.

[37] Y.H. Yeom, M.J. Li, W.M.H. Sachtler, E. Weitz, Journal of Catalysis 246 (2007) 413-427.

[38] H. He, Y.B. Yu, Catalysis Today 100 (2005) 37-47.

[39] A. Obuchi, I. Kaneko, J. Oi, A. Ohi, A. Ogata, G.R. Bamwenda, S. Kushiyama, Applied Catalysis B-Environmental 15 (1998) 37-47.

[40] Y.B. Yu, H. He, Q.C. Feng, H.W. Gao, X. Yang, Applied Catalysis B-Environmental 49 (2004) 159-171.

[41] N. Macleod, R.M. Lambert, Chemical Communications (2003) $1300-1301$.

[42] A. Sultana, M. Haneda, T. Fujitani, H. Hamada, Catalysis Letters 114 (2007) 96-102.

[43] X. She, M. Flytzani-Stephanopoulos, Journal of Catalysis 237 (2006) 79-93.

[44] P. Sazama, L. Capek, H. Drobna, Z. Sobalik, J. Dedecek, K. Arve, B. Wichterlova, Journal of Catalysis 232 (2005) 302-317.

[45] F.C. Meunier, J.P. Breen, V. Zuzaniuk, M. Olsson, J.R.H. Ross, Journal of Catalysis 187 (1999) 493-505.

[46] S.T. Korhonen, A.M. Beale, M.A. Newton, B.M. Weckhuysen, Journal of Physical Chemistry C 115 (2011) 885-896.

[47] M.K. Kim, P.S. Kim, J.H. Baik, I.S. Nam, B.K. Cho, S.H. Oh, Applied Catalysis B-Environmental 105 (2011) 1-14.

[48] D.Y. Yoon, J.H. Park, H.C. Kang, P.S. Kim, I.S. Nam, G.K. Yeo, J.K. Kil, M.S. Cha, Applied Catalysis B-Environmental 101 (2011) 275 282.

[49] V.I. Parvulescu, B. Cojocaru, V. Parvulescu, R. Richards, Z. Li, C. Cadigan, P. Granger, P. Miquel, C. Hardacre, Journal of Catalysis 272 (2010) 92-100.

[50] K. Sato, T. Yoshinari, Y. Kintaichi, M. Haneda, H. Hamada, Applied Catalysis B-Environmental 44 (2003) 67-78.

[51] F. Thibault-Starzyk, E. Seguin, S. Thomas, M. Daturi, H. Arnolds, D.A. King, Science 324 (2009) 1048-1051.

[52] F. Can, A. Flura, X. Courtois, S. Royer, G. Blanchard, P. Marecot, D. Duprez, Catalysis Today 164 (2011) 474-479.

[53] X.L. Zhang, H. He, Z.C. Ma, Catalysis Communications 8 (2007) 187-192.

[54] T.E. Hoost, R.J. Kudla, K.M. Collins, M.S. Chattha, Applied Catalysis B: Environmental 13 (1997) 59-67.

[55] M.C. Kung, H.H. Kung, Topics in Catalysis 10 (2000) 21-26.

[56] M. Bonne, Optimisation de la synthèse de matériaux poreux de haute surface, composés d'oxydes simples $\left(\mathrm{SiO}_{2}, \mathrm{TiO}_{2}, \mathrm{Al}_{2} \mathrm{O}_{3}\right)$ et 
d'oxydes mixtes (perovskites), pour des applications en catalyse hétérogène, Chimie Organique, minérale, industrielle, Université de Poitiers, Poitiers, 2010.

[57] T. Sato, S. Goto, Q. Tang, S. Yin, Journal of Materials Science 43 (2008) 2247-2253.

[58] S. Khabtou, T. Chevreau, J.C. Lavalley, Microporous Materials 3 (1994) 133-148.

[59] K.A. Bethke, H.H. Kung, Journal of Catalysis 172 (1997) 93-102.

[60] M. Luo, B. Zhu, L. Zhou, X. Yuan, 24 (1996) 201-206.

[61] A. Musi, P. Massiani, D. Brouri, J.M. Trichard, P. Da Costa, Catalysis Letters 128 (2009) 25-30.

[62] J. Texter, J.J. Hastrelter, J.L. Hall, Journal of Physical Chemistry 87 (1983) 4690-4693.

[63] M. Matsuoka, E. Matsuda, K. Tsuji, H. Yamashita, M. Anpo, Chemistry Letters (1995) 375-376.

[64] A.N. Pestryakov, A.A. Davydov, Journal of Electron Spectroscopy and Related Phenomena 74 (1995) 195-199.

[65] B. Inceesungvorn, J. López-Castro, J.J. Calvino, S. Bernal, F.C. Meunier, C. Hardacre, K. Griffin, J.J. Delgado, Applied Catalysis A: General 391 (2011) 187-193.

[66] P. Mulvaney, A. Henglein, Journal of Physical Chemistry 94 (1990) 4182-4188.

[67] T. Linnert, P. Mulvaney, A. Henglein, H. Weller, Journal of the American Chemical Society 112 (1990) 4657-4664.

[68] E. Gachard, J. Belloni, M.A. Subramanian, Journal of Materials Chemistry 6 (1996) 867-870.

[69] J. Michalik, J. Sadlo, T. Kodaira, S. Shimomura, H. Yamada, Journal of Radioanalytical and Nuclear Chemistry 232 (1998) 135-137.

[70] Z.J. Li, M. Flytzani-Stephanopoulos, Journal of Catalysis 182 (1999) 313-327.

[71] J. Shibata, Y. Takada, A. Shichi, S. Satokawa, A. Satsuma, T. Hattori, Journal of Catalysis 222 (2004) 368-376.

[72] A. Satsuma, J. Shibata, A. Wada, Y. Shinozaki, T. Hattori, Studies in Surface Science and Catalysis \&lt;span style=""> 145 (2002) 235-238.

[73] H. Knozinger, P. Ratnasamy, Catalysis Reviews-Science and Engineering 17 (1978) $31-70$.

[74] A.A. Tsyganenko, V.N. Filimonov, Journal of Molecular Structure 19 (1973) 579-589.

[75] A.A. Tsyganenko, V.N. Filimonov, Spectroscopy Letters 13 (1980) 583-592.

[76] F. Can, A. Travert, V. Ruaux, J.P. Gilson, F. Mauge, R. Hu, R.F. Wormsbecher, Journal of Catalysis 249 (2007) 79-92.

[77] C. Morterra, G. Ghiotti, F. Boccuzzi, S. Coluccia, Journal of Catalysis 51 (1978) 299-313.

[78] G. Busca, V. Lorenzelli, V.S. Escribano, R. Guidetti, Journal of 
Catalysis 131 (1991) 167-177.

[79] J. Popovic, E. Tkalcec, B. Grzeta, S. Kurajica, B. Rakvin, American Mineralogist 94 (2009) 771-776.

[80] E.P. Parry, Journal of Catalysis 2 (1963) 371-379.

[81] Y.H. Yeom, M.J. Li, W.M.H. Sachtler, E. Weitz, Journal of Catalysis 238 (2006) 100-110.

[82] A. Le Valant, N. Bion, F. Can, D. Duprez, F. Epron, Applied Catalysis B-Environmental 97 (2010) 72-81.

[83] M.S. Ghattas, Journal of Molecular Catalysis a-Chemical 248 (2006) 175-180.

[84] W.-L. Dai, Y. Cao, L.-P. Ren, X.-L. Yang, J.-H. Xu, H.-X. Li, H.-Y. He, K.-N. Fan, Journal of Catalysis 228 (2004) 80-91.

[85] S. Kameoka, T. Chafik, Y. Ukisu, T. Miyadera, Catalysis Letters 51 (1998) $11-14$.

[86] Y. Yeom, M. Li, A. Savara, W. Sachtler, E. Weitz, Catalysis Today 136 (2008) 55-63. 